\title{
Fe-Ti-Zr metasomatism in the oceanic mantle due to extreme differentiation of tholeiitic melts (Moa-Baracoa ophiolite, Cuba)
}

\author{
Núria Pujol-Solà ${ }^{\mathrm{a}, *}$, Joaquín A. Proenza ${ }^{\mathrm{a}}$, Antonio Garcia-Casco ${ }^{\mathrm{b}, \mathrm{c}}$, José María González-Jiménez ${ }^{\mathrm{b}}$, \\ Manuel J. Román-Alpiste ${ }^{\mathrm{c}}$, Carlos J. Garrido ${ }^{\mathrm{c}}$, Joan Carles Melgarejo ${ }^{\mathrm{a}}$, Fernando Gervilla ${ }^{\mathrm{b}, \mathrm{c}}$, Xavier Llovet ${ }^{\mathrm{d}}$

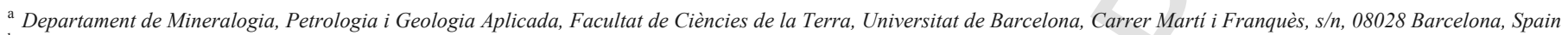 \\ ${ }^{\mathrm{b}}$ Departamento de Mineralogía y Petrología, Facultad de Ciencias, Universidad de Granada, Avda. Fuentenueva, s/n, 18071 Granada, Spain \\ c Instituto Andaluz de Ciencias de la Tierra (CSIC-UGR), Avda. de las Palmeras 4, E-18100 Armilla, Granada, Spain \\ d Centres Científics i Tecnologics, Universitat de Barcelona, Carrer de Lluís Solé i Sabarís, 1-3, 08028 Barcelona, Spain
}

\section{A R T I C L E IN F O}

\section{Article history:}

Received 17 November 2019

Received in revised form 28 January 2020

Accepted 9 February 2020

Available online $\mathrm{xxx}$

\section{Keywords:}

ophiolitic chromitite

zircon coronas

HFSE minerals

evolved MORB melt

modal metasomatism

\begin{abstract}
A B S T R A C T
Ti-rich amphibole, Mg-rich ilmenite, baddeleyite, zirconolite, srilankite, and zircon are important high-field-strength elements (HFSE) bearing phases in the Potosí chromitite bodies located in the Moho Transition Zone of the Cretaceous Moa-Baracoa suprasubduction zone ophiolite (eastern Cuba). Such HFSE-bearing phases were found in the interaction zone between gabbroic intrusions and chromitite pods. In addition to HFSE-bearing minerals, the studied samples are composed of $\mathrm{Fe}^{3+}$ and Ti-rich chromite, olivine $\left(\mathrm{Fo}_{86-90}\right)$, clinopyroxene $\left(\mathrm{En}_{44-49}\right)$, plagioclase $\left(\mathrm{An}_{51-56}\right)$, orthopyroxene $\left(\mathrm{En}_{84-94}\right)$, F-rich apatite, and Fe-Cu-Ni sulfides. The studied ilmenite hosting $\mathrm{Zr}$ oxides (baddeleyite, zirconolite, and srilankite) contains up to $13 \mathrm{wt} . \% \mathrm{MgO}$. The Potosí zirconolite is the first record of this mineral in ophiolitic chromitites and non-metamorphic ophiolite units, and it has relatively high REE contents (up to $10 \mathrm{wt} . \%$ of $\mathrm{REE}_{2} \mathrm{O}_{3}$ ) and the highest concentrations in $\mathrm{Y}_{2} \mathrm{O}_{3}$ (up to $11 \mathrm{wt} . \%$ ) reported so far in zirconolite from terrestrial occurrences. Zircon is observed forming coronas surrounding ilmenite grains in contact with silicate minerals, and is characterized by very low $\mathrm{U}$ and $\mathrm{Pb}$ contents. The zircons formed after high temperature $\mathrm{Zr}$ diffusion in ilmenite (exsolution) and a subsequent reaction along grain boundaries following crystallization. Finally, U-Pb dating of baddeleyite exsolutions within ilmenite yielded an average age of $134.4 \pm 14 \mathrm{Ma}$, which provides the first ever dating for a metasomatic event in Potosí that matches well (within uncertainty) the formation age of the oceanic crust of the eastern Cuba ophiolite. We propose that the occurrence of HFSE- and REE-bearing minerals in the Potosí chromite deposit is the result of a two stage process: first, water-rich and HFSE-rich residual melts are produced by intercumulus crystal fractionation after an evolved MORB (BABB)-like melt; and secondly, these residual melt fractions escaped the solidifying mush and extensively reacted and metasomatized the surrounding chromitites, crystallizing HFSE- and REE-bearing minerals and Fe-Cu-Ni sulfides.
\end{abstract}

(C) 2020

\section{Introduction}

Mantle metasomatism is a process by which the infiltration of melts or fluids through the Earth's upper mantle produces chemical and/or mineralogical modification of peridotites and associated rocks (Bodinier et al., 1990; Constantin, 1999; Menzies and Hawkesworth, 1987). This process leads either to the removal or addition of components of the original rock to varying extents, depending on the melt-fluid/rock ratio, the compositional nature of the metasomatic agent and the mode of infiltration (i.e., porous flow versus open fractures; O'Reilly and Griffin, 2013). As a result of variable melt/rock ra-

\footnotetext{
* Corresponding author.

Email addresses: npujolsola@ub.edu (N. Pujol-Solà); japroenza@ub.edu (J.A. Proenza); agcasco@ugr.es (A. Garcíia-Casco); jmgonzj@ugr.es (J.M. González-Jiménez); mj.roman@csic.es (M.J. Román-Alpiste); carlos.garrido@ csic.es (C.J. Garrido); joan.carles.melgarejo.draper@ub.edu (J.C. Melgarejo); gervilla@ugr.es (F. Gervilla); xavier@ccit.ub.edu (X. Llovet)
}

tios through the upper mantle, metasomatism leaves behind different fingerprints in the infiltrated rocks such as newly formed minerals (Bedini et al., 1997; Bodinier et al., 1990). These minerals may be distinct to those originally forming the peridotite, giving rise to the so-called modal metasomatism, or alternatively they are identical to those already existing in the upper mantle rock, which produce the so-called stealth metasomatism (O'Reilly and Griffin, 2013). Recent advances of in-situ microanalytical techniques such as laser ablation ICPMS have allowed to better define the third style of metasomatism, known as cryptic metasomatism, produced under low melt/rock ratios and characterized by the modification of the distribution of major, minor, and trace elements in peridotite-forming minerals (O'Reilly and Griffin, 2013 and references therein). To date, most efforts in understanding mantle metasomatism have been focused on the study of ultramafic xenoliths and exhumed ultramafic massifs that have sampled the subcontinental lithospheric mantle (SCLM) underlying cratonic and off-craton regions of the Earth (Bodinier et al., 2008; Coltorti et al., 2004; Le Roux et al., 2007; Lenoir et al., 2001; 
Soustelle et al., 2009). In the SCLM, these three styles of metasomatism are very well preserved and have been identified to originate via a variety of metasomatic agents, including supercritical fluids and a variety of silicate liquids including silica-saturated, high-Na and high-K alkaline basaltic, as well as kimberlitic and carbonatitic compositions (e.g., Bodinier et al., 1990; Ionov et al., 1999; Coltorti et al., 1999, 2000; Greégoire et al., 2000; Laurora et al., 2001; Dawson, 2002; Lorand et al., 2004; Scamberulli et al., 2009; González-Jiménez et al., 2014a; Akizawa et al., 2017; Tassara et al., 2018). However, modal metasomatism is relatively underexplored in the mantle rocks of "normal oceanic lithosphere", as numerous studies focused on oceanic islands such as Hawaii, Kerguelen or Canary islands.

Reactive melt percolation, partial dissolution, and melt crystallization are common processes in extensional settings, causing large compositional variations in the lithospheric mantle (Bodinier and Godard, 2003; Kelemen et al., 1995a, 1995b; Rampone et al., 2018; Warren and Shimizu, 2010 and references therein). The resulting lithologies in the thermal boundary layer (TBL) and in the lithospheric mantle include replacive harzburgites, dunites, and impregnated peridotites with plagioclase and pyroxene (Basch et al., 2019a, 2019b; Rampone et al., 2018 and references therein). Ascending melts also lead to the formation of gabbroic rocks (olivine-gabbro, gabbro, gabbronorite, and ferrogabbro or oxide gabbro), often emplaced as intrusive dikes crosscutting peridotites in slow- (e.g., Morishita et al., 2004) and fast-spreading environments (e.g., Constantin, 1999). Morishita et al. (2004) reported an example of extreme metasomatism in the slow-spreading SW Indian Ridge, where extremely differentiated mantle-derived melts infiltrate oceanic peridotites thus forming Fe-Ti-rich gabbroic veins with a complex mineral assemblage including srilankite, Mg-rich ilmenite, apatite, and rutile.

Similar processes, such as multi-stage melt infiltration and magma-peridotite interaction, are recorded in many ophiolites (Kelemen et al., 1992, 1995b; Python and Ceuleneer, 2003), especially in the Moho Transition Zone (hereafter MTZ) of ophiolitic sequences. The MTZ, located between residual peridotites and layered crustal gabbros, is characterized by variable thickness but significant lateral continuity of a rock assemblage made of harzburgites, dunites, chromitites, wehrlites, troctolites, pyroxenites, in addition to gabbroic sills and dikes. Many bodies of dunite, wehrlite, troctolite, and websterite originated from impregnation of residual peridotites (e.g., Marchesi et al., 2006), while extensive melt-rock interaction by reactive porous flow leads to selective enrichment in incompatible elements (Basch et al., 2019a).

Eastern Cuban ophiolites are characterized by large exposures of the MTZ, where interaction between residual peridotites and percolating melts have resulted in the formation of dunite bodies and associated chromitites (Marchesi et al., 2006; Proenza et al., 1999a). In the Potosí chromite deposit, Proenza et al. (2001) reported a very peculiar mineral assemblage made up of $\mathrm{Fe}-\mathrm{Ni}-\mathrm{Cu}$ sulfides, apatite, amphibole, and unidentified oxides of $\mathrm{Ti}, \mathrm{Zr}, \mathrm{Y}, \mathrm{Ca}, \mathrm{Fe}, \mathrm{Hf}$, and REE along the contact between the chromitite pods and intruding gabbroic dikes.

The present study explores in detail the metasomatic assemblage and major and trace element composition of uncommon HFSE-bearing minerals (Mg-rich ilmenite, Hf-bearing baddeleyite, REE-rich zirconolite, srilankite, zircon) found in the interaction zone between gabbroic intrusions and chromitite pods. This is an unprecedented scenario where a highly evolved tholeiitic melt interacted with chromitite in the MTZ, producing a unique metasomatic assemblage enriched in $\mathrm{Fe}, \mathrm{Ti}, \mathrm{Zr}$, and other high-field-strength elements (HFSE).

\section{Geological setting}

The Mesozoic Cuban ophiolite belt, that outcrops discontinuously over more than $1,000 \mathrm{~km}$ along length of the island (Fig. 1a), represents the largest exposure of ophiolites in the Caribbean region (Garcia-Casco et al., 2006; Iturralde-Vinent, 1996; Iturralde-Vinent et al., 2016; Lewis et al., 2006). This belt represents slices of oceanic lithosphere obducted during Latest Cretaceous to Eocene times as a consequence of the collision of the Caribbean volcanic arc with the Jurassic-Cretaceous passive margins of the continental Maya block and the Bahamas platform (Iturralde-Vinent et al., 2006, 2016; Garcia-Casco et al., 2008a).

In Eastern Cuba, ophiolitic bodies are grouped into the Mayarí-Baracoa Ophiolite Belt (MBOB). This region is characterized by NE-directed tectonic nappes accreted in the Late Cretaceous - Earliest Paleocene (Cobiella-Reguera, 2005; Iturralde-Vinent et al., 2006). These nappes include Early to Late Cretaceous oceanic arc sequences (Marchesi et al., 2007; Proenza et al., 2006), some of them subducted during the latest Cretaceous (Garcia-Casco et al., 2008a and references therein), the MBOB (Proenza et al., 1999b) and closely associated Early Cretaceous low-P and high-P (subduction-related) serpentinite-matrix mélanges (Garcia-Casco et al., 2008b; Blanco-Quintero et al., 2010, 2011; Lázaro et al., 2009, 2016; Cárdenas-Párraga et al., 2017), a Late Cretaceous metamorphic sole (Lázaro et al., 2013, 2015), and high-pressure metamorphosed passive-margin sediments of the Caribbeana terrane (Garcia-Casco et al., 2008a and references therein). The MBOB (170 km long, 10 - $30 \mathrm{~km}$ wide) comprises two allochthonous massifs separated by major fault zones: the Mayarí-Cristal (exposing $5 \mathrm{~km}$ of mantle section) to the west and the Moa-Baracoa (2.2 km of peridotites) to the east (Fig. 1b; Proenza et al., 1999a, 1999b; Marchesi et al., 2006). The ophiolite includes the mantle and crustal sequences, is highly dismembered, and represents MOR-like lithosphere formed in the suprasubduction zone setting of the intra-oceanic Caribbean arc (Gervilla et al., 2005; Marchesi et al., 2006, 2007; Proenza et al., 1999b, 2018). More than 250 chromite deposits and occurrences have been described in the MBOB (Gervilla et al., 2005; González-Jiménez et al., 2011; Proenza et al., 1999b). They are divided into three mining districts according to the composition of chromite forming the chromitite ore: Mayarí (high-Cr), Sagua de Tánamo (high-Cr and high-Al) and Moa-Baracoa (high-Al) (Fig. 1b).

\subsection{The Moa-Baracoa ophiolitic massif}

The Moa-Baracoa massif consists of mantle tectonite harzburgite with subordinate dunite and a MTZ associated with layered gabbros (about $500 \mathrm{~m}$ thick) and mafic volcanic rocks (Fig. 1c; Marchesi et al., 2006). Towards the top of the mantle tectonites, harzburgite contains increasing amounts of dunite, gabbro sills, and chromitite, all forming elongated pseudotabular bodies oriented parallel to the foliation of the host harzburgite, as well as discordant dikes of wehrlite, troctolite, olivine gabbro, and pegmatitic gabbro (Flint et al., 1948; Guild, 1947; Marchesi et al., 2006; Proenza et al., 1999a, 1999b, 2001). The peridotites and layered gabbros are in tectonic contact with the pillow basalts of the Morel formation ( 88 - $91 \mathrm{Ma}$; Iturralde-Vinent et al., 2006), which show a back-arc geochemical affinity. Marchesi et al. (2006) established the genetic link between the Morel formation and the cumulate gabbros of the Moa-Baracoa massif. Therefore, the Moa-Baracoa Ophiolite Massif is interpreted to have formed in a back-arc environment (Gervilla et al., 2005; Lázaro et al., 2015; Proenza et al., 2006). 


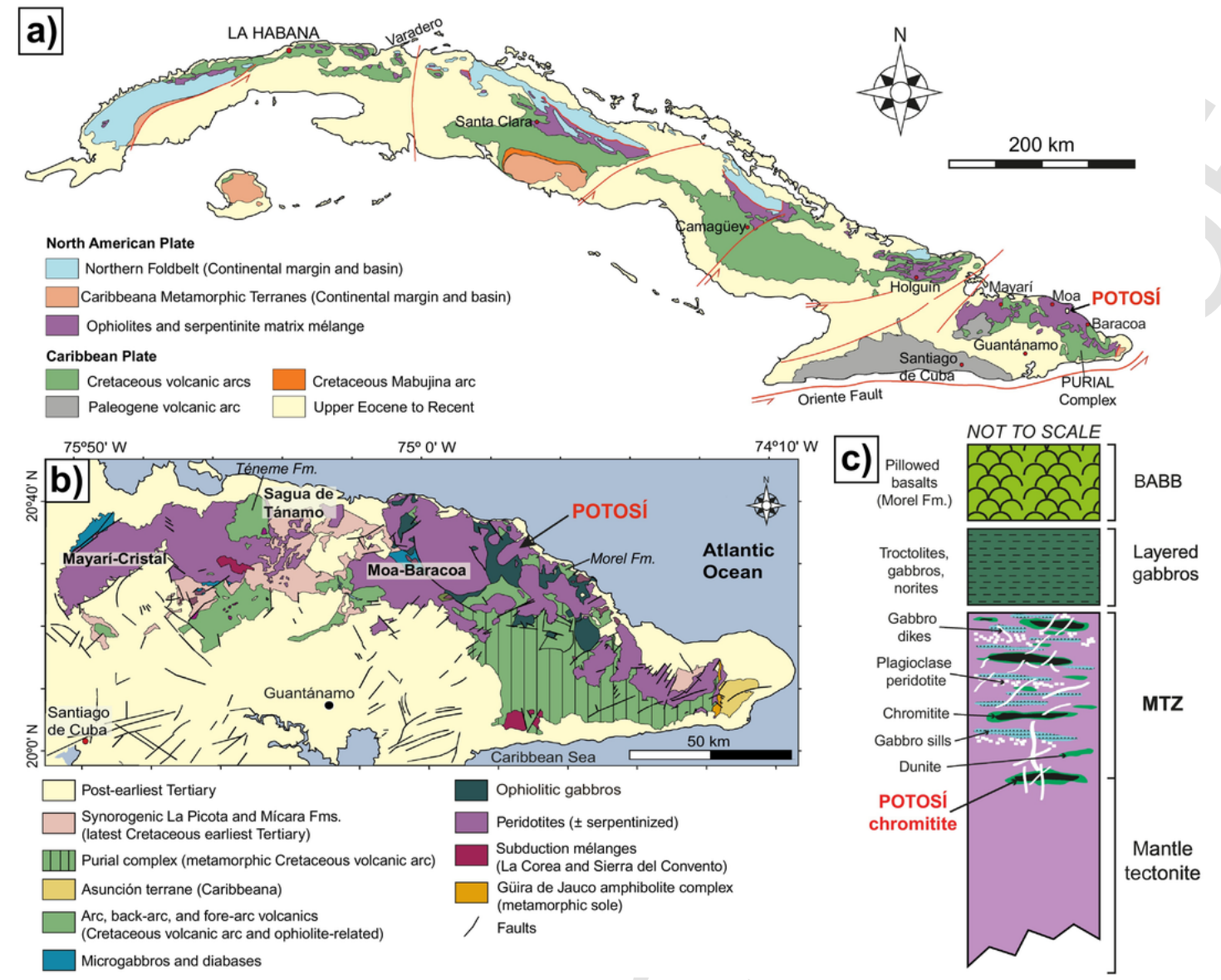

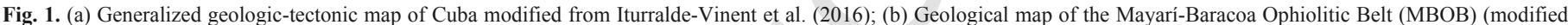

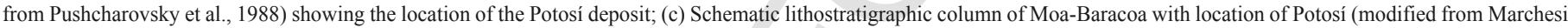
et al., 2006).

\subsection{The Potosi chromitites and the gabbroic intrusions}

The Potosí chromitites are located $800 \mathrm{~m}$ deeper than the layered gabbros forming the MTZ at the Moa-Baracoa Ophiolitic Massif (Fig. 1c) (Proenza et al., 2001). They form lenses of variable sizes and irregular shapes (tabular to lenticular) hosted in dunite within harzburgite. The bodies are oriented $\mathrm{N} 40^{\circ} \mathrm{E}$ to $\mathrm{N} 74^{\circ} \mathrm{E}$ with dips between $32^{\circ}$ and $45^{\circ}$ to the NW, usually filling the foliation of the host peridotites. Several generations of gabbroic intrusions crosscut the chromitite bodies, usually following pull-apart fractures with brecciated zones at their margins (Fig. 2a-d; Proenza et al., 2001). Dikes have highly variable thicknesses, from a few centimeters to $2 \mathrm{~m}$ across and locally show a distinct grain-size zoning with pegmatitic textures in the dike cores that reach grain sizes larger than $15 \mathrm{~cm}$ (Fig. 2c-e) and finer grain sizes closer to the contacts with chromitite. Disrupted fragments of chromitite occur as inclusions within the gabbroic intrusions (Fig. 2d). The contacts between the chromitites and the gabbroic intrusions may be either neat (Fig. 2e) or gradational, the latter characterized by a brecciated zone where chromite is included within the gabbroic dikes (Fig. 2f).

Chromitite in Potosí can be classified as: i) ordinary podiform chromitite, preexistent to gabbroic intrusions, or ii) metasomatized chromitite, associated with or intruded by gabbroic dikes and denoted as "brecciated chromite ore" and "sulfide-rich chromite ore" by Proenza et al. (2001). Ordinary chromitites represent more than 90 vol. $\%$ of the ore body and show mineralogical, textural and chemi- cal features similar to other Al-rich chromitite bodies in the MBOB (Gervilla et al., 2005; Proenza et al., 1999b) and ophiolitic complexes worldwide (González-Jiménez et al., 2014b; Arai and Miura, 2016 and references in these papers). Metasomatized chromitite is composed mostly of recrystallized Ti- and $\mathrm{Fe}^{3+}$ - rich chromite, Ti-rich amphibole, orthopyroxene, clinopyroxene, plagioclase, and $\mathrm{Fe}-\mathrm{Cu}-\mathrm{Ni}$ sulfides, the latter formed by fractionation of immiscible sulfide liquid segregated from the mafic intrusions (Proenza et al., 2001).

\section{Studied samples and analytical techniques}

\subsection{Studied samples}

A total of 20 hand samples and 38 thin sections were examined for this study (Appendix 1), including ordinary chromitite and its host peridotite ( 5 samples), metasomatized chromitite (11 samples), and gabbroic dikes (4 samples) (Fig. 2a-b). Most samples were taken from the outcrops of old mine works and some were collected in the mine dumps.

\subsection{Analytical techniques}

Modal composition of the POT-2 sample was calculated using point counting on thin section with the software JMicroVision. Whole rock geochemical analyses were performed at the Centre for Scientific Instrumentation (CIC) of the University of Granada. Samples were carefully prepared by removing secondary veins and weather- 

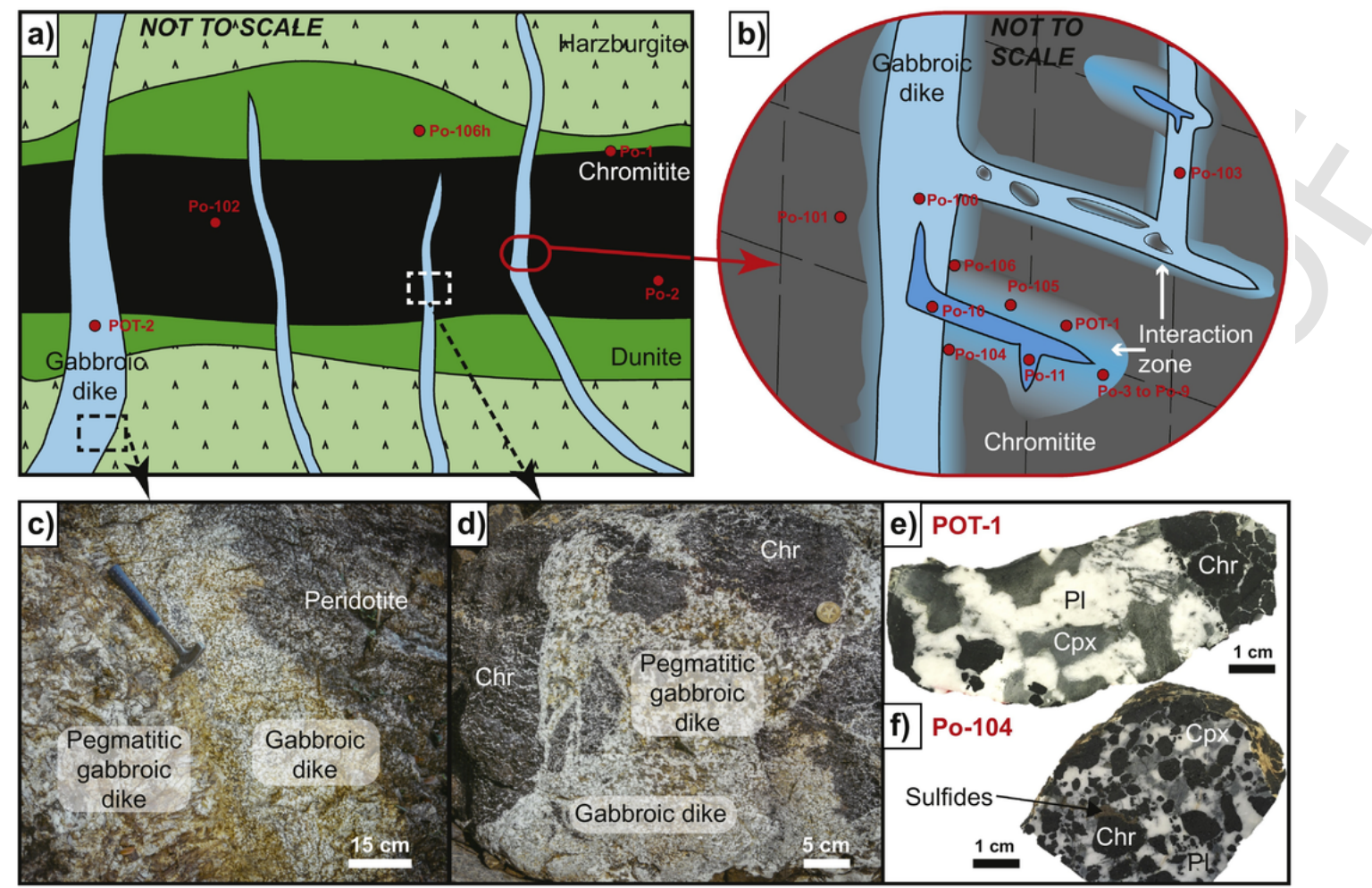

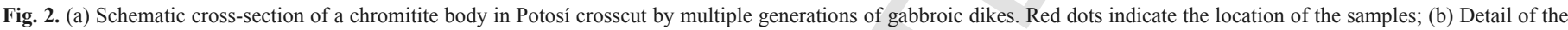

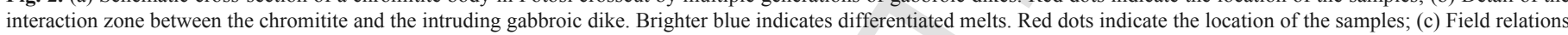

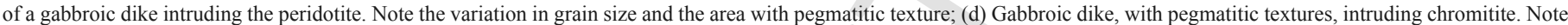

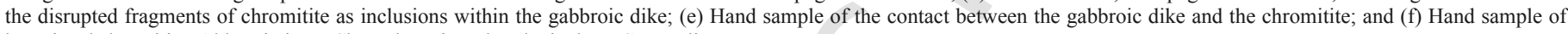
brecciated chromitite. Abbreviations: $\mathrm{Chr}$ - chromite, $\mathrm{Pl}$ - plagioclase, $\mathrm{Cpx}$ - clinopyroxene.

ing products before crushing and powdering in an agate mill. Major element and $\mathrm{Zr}$ concentrations were determined by X-ray fluorescence (XRF) spectrometry on glass beads $(\sim 0.6 \mathrm{~g}$ of powdered sample diluted in $6 \mathrm{~g}$ of $\mathrm{Li}_{2} \mathrm{~B}_{4} \mathrm{O}_{7}$ ) using a Philips Magix Pro (PW-2240). Precision was better than $\pm 1.5 \%$ for an analyte concentration of $10 \mathrm{wt} . \%$ and the precision for $\mathrm{Zr}$ was better than $\pm 4 \%$ at $100 \mathrm{ppm}$ concentration. The analyses were recalculated to an anhydrous basis (100 wt.\%). Trace elements were analyzed by ICP Mass Spectroscopy (ICP-MS) at the same institution. $\sim 100 \mathrm{mg}$ of sample were digested with $\mathrm{HNO}_{3}$ $+\mathrm{HF}$ in a Teflon lined vessel at $180^{\circ} \mathrm{C}$ and $\sim 200$ psi for 30 min, evaporated to dryness, and subsequently dissolved in $100 \mathrm{ml}$ of $4 \mathrm{vol} . \%$ $\mathrm{HNO}_{3}$. During analytical sessions, the procedural blanks and reference materials PMS, WSE, UBN, BEN, BR, and AGV were run as unknowns and primary standards to obtain concentrations (Govindaraju, 1994). Precision was better than $\pm 2 \%$ and $\pm 5 \%$ for analyte concentrations of 50 and $5 \mathrm{ppm}$, respectively. Major and trace element bulk analyses results are presented in Appendix 2.

Polished thin sections were studied in detail by optical microscopy and scanning electron microscopy, using both a Quanta 200 FEI XTE 325/D8395 scanning electron microscope (SEM) and a JEOL JSM-7100 field-emission SEM at the Universitat de Barcelona (CCiTUB). Operating conditions were $15-20 \mathrm{kV}$ accelerating voltage and $5 \mathrm{nA}$ beam current. Quantitative electron microprobe analyses (EMPA) were also conducted at the CCiTUB using both CAMECA SX50 and JEOL JXA-8230 electron microprobes, operating in wavelength-dispersive spectroscopy (WDS) mode. The analytical conditions are described in Appendix 3.

Trace element compositions of chromite, ilmenite, clinopyroxene, orthopyroxene, olivine, amphibole, apatite, zircon, and baddeleyite were measured in-situ on polished thin sections $(30 \mu \mathrm{m})$ by an induc- tively coupled mass spectrometer Agilent 8800 QQQ ICP-MS interfaced to a laser ablation extraction line Photon Machines Analyte Excite 193 at the Instituto Andaluz de Ciencias de la Tierra (CSIC-UGR, Granada). The analytical conditions are described in Appendix 3. Six grains of baddeleyite were analyzed for $\mathrm{U} / \mathrm{Pb}$ isotopes with the same equipment at the same institution. A spot diameter of $30 \mu \mathrm{m}$ was used with the same analytical conditions as for zircon. Phalaborwa baddeleyite was used as a reference material and in-house Mogok baddeleyite for secondary/validation. Data (Appendix 4) were reduced using Igor Pro iolite 3.6 software, VisualAge DR, ET-Redux, and Isoplot for data presentation.

\section{Results}

\subsection{Petrological features of the gabbroic intrusions}

Two types of gabbroic intrusions have been characterized in Potosí (Fig. 3). The first type (POT-2) corresponds to a melagabbro (Fig. 3a) containing olivine (64\%), clinopyroxene (21\%), plagioclase $(14 \%)$, orthopyroxene $(<1 \%)$, and accessory oxides with a general coarse grain size. Olivine and plagioclase are cumulus minerals and clinopyroxene is intercumulus (mesocumulate texture). Clinopyroxene reaches up to $2 \mathrm{~cm}$ in length and develops a poikilitic texture. The major and trace element composition of this type of intrusion (Appendix 2) is similar to the primitive sills and dikes crosscutting the MTZ in the Moa-Baracoa massif reported by Marchesi et al. (2006) (Fig. 3b, c). The trace element contents are slightly richer than chondrite and the chondrite-normalized REE pattern shows a slightly positive slope from LREE to MREE and a flat pattern from MREE to HREE (Fig. $3 d, e)$. 


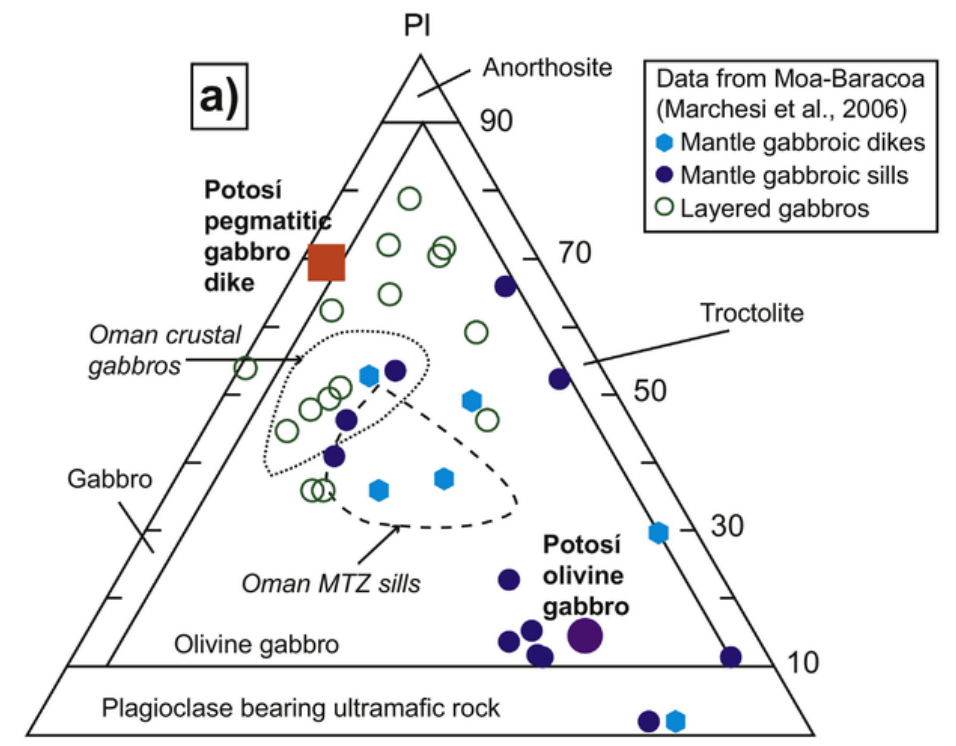

Px

Ol
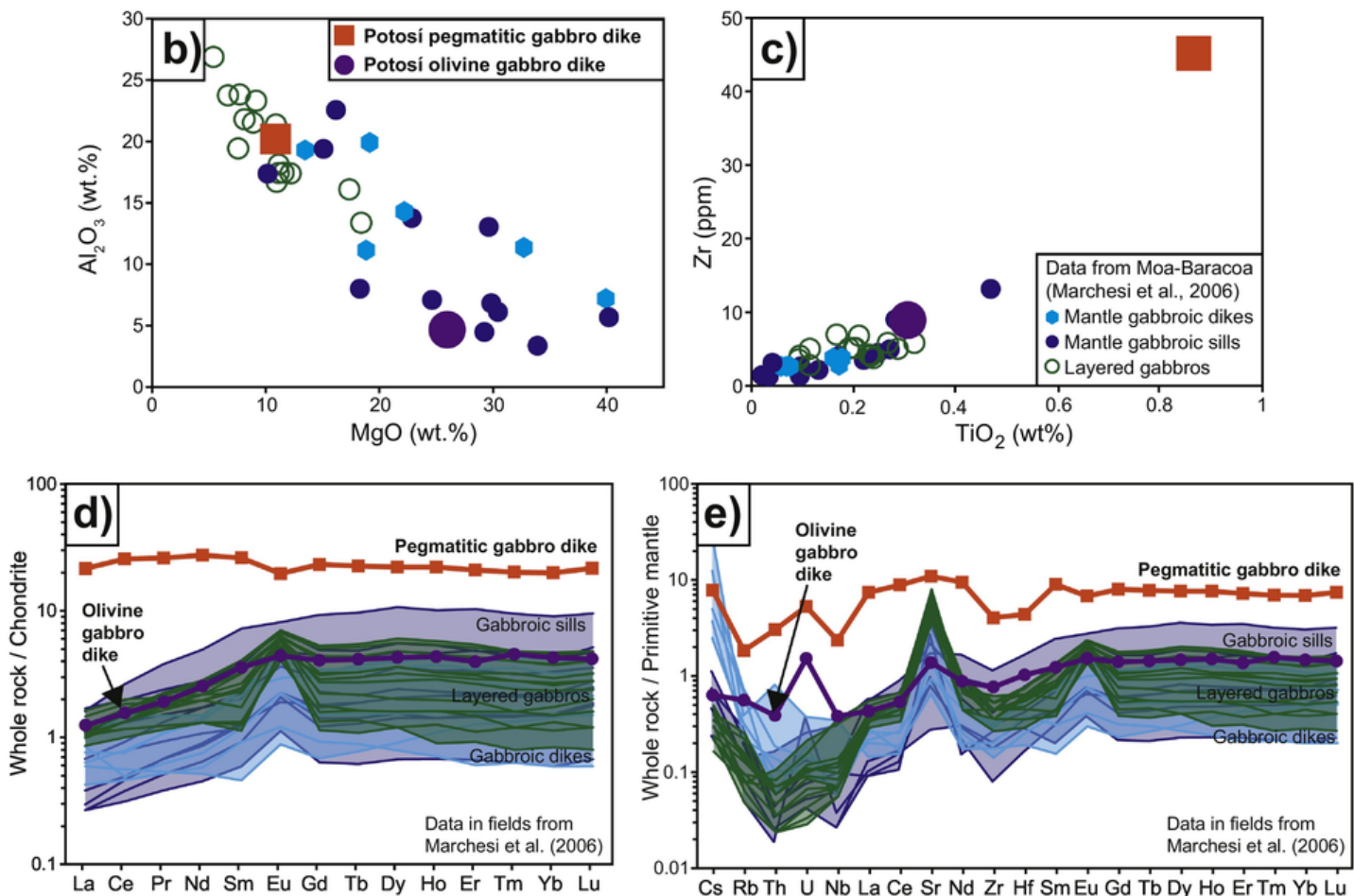

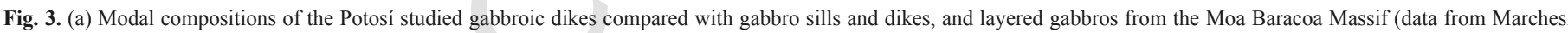

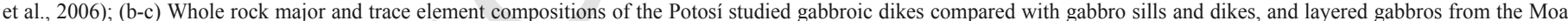

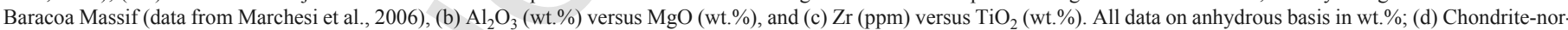

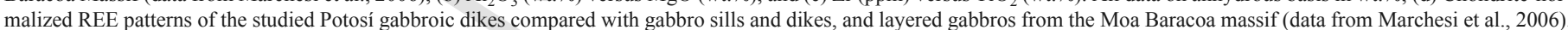

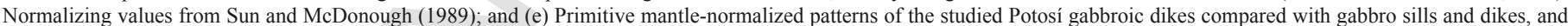
layered gabbros from the Moa Baracoa Massif (data from Marchesi et al., 2006). Normalizing values from Sun and McDonough (1989).

The second type of gabbroic intrusion (POT-1) corresponds to a leucogabbro dike with pegmatitic texture (Fig. 2e, 3a) containing plagioclase $(70 \%)$ and clinopyroxene $(28 \%)$ crystals up to $3 \mathrm{~cm}$ in length with accessory oxides (around $2 \%$ ). The major element composition of the dike (Appendix 2) is similar to the more evolved gabbroic sills and dikes (Fig. 3b) of the Moa-Baracoa massif (Marchesi et al., 2006). However, it shows an important enrichment in trace elements (Appendix 2), notably in $\mathrm{Zr}$ (Fig. 3c). The chondrite-normal- ized REE (Fig. 3d) and primitive mantle-normalized trace element (Fig. 3e) patterns show enrichment by one order of magnitude compared to those of the Moa-Baracoa gabbroic dikes, sills, and layered gabbros (Marchesi et al., 2006).

Plagioclase crystals (up to $2 \mathrm{~cm}$ ) in the gabbro dike show polysynthetic twinning (Fig. 4a) and partial alteration to (clino)zoisite and fine-grained phyllosilicate aggregates. Fresh plagioclase shows labradorite composition $\left(\mathrm{An}_{51}-\mathrm{An}_{56}\right)$ (Appendix 5) with lim- 


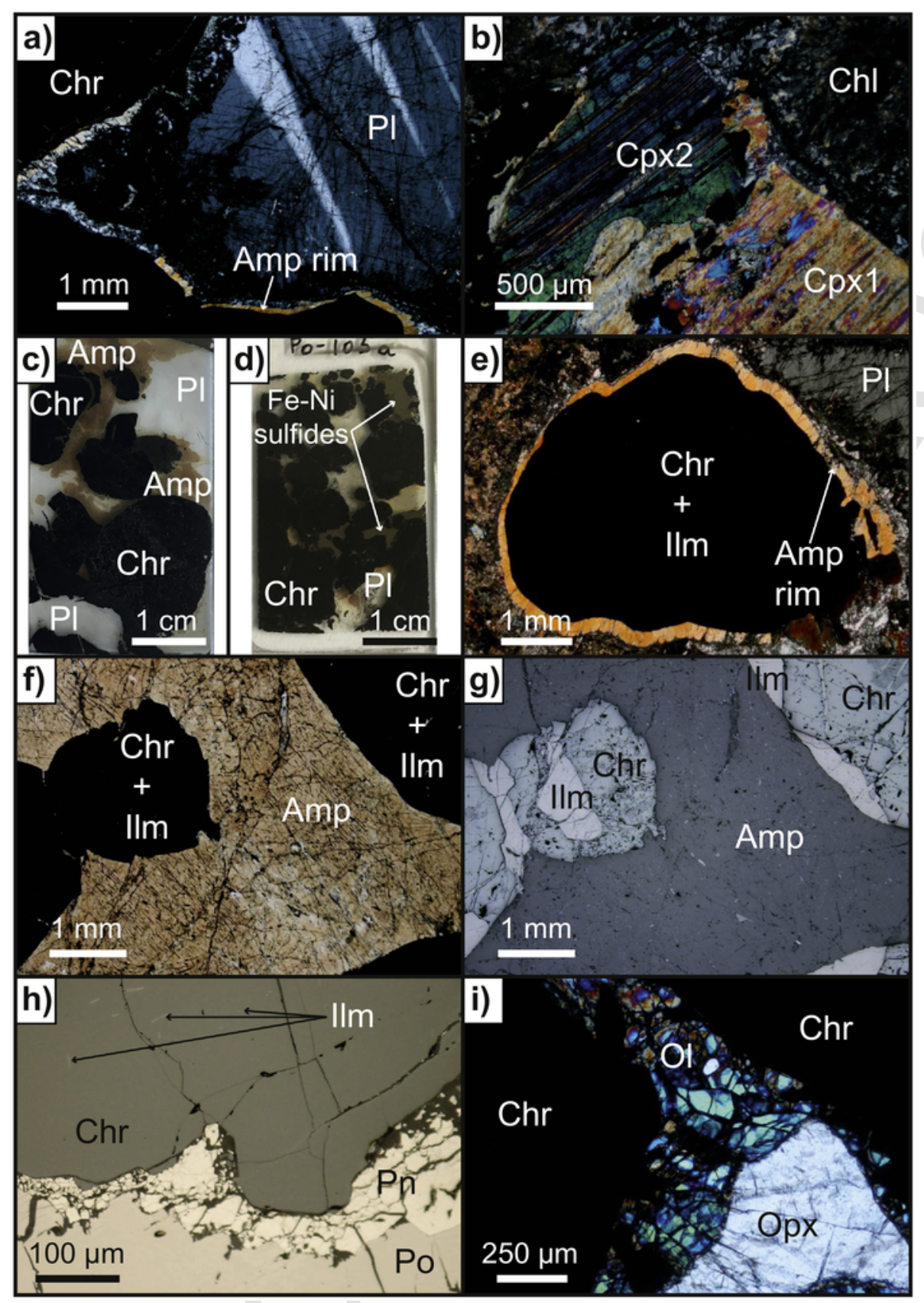

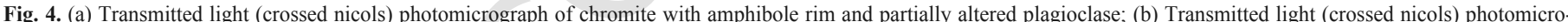

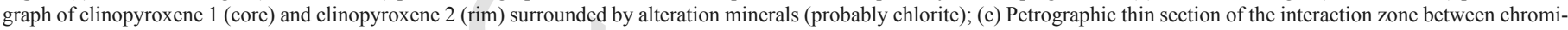

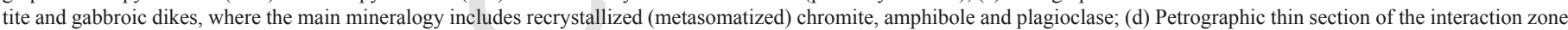

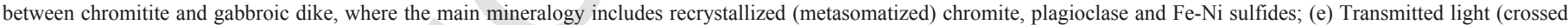

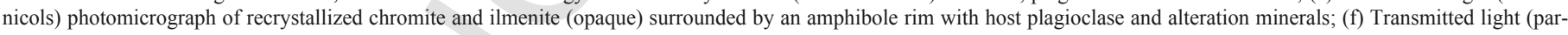

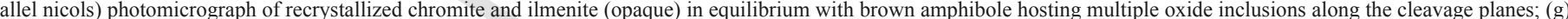

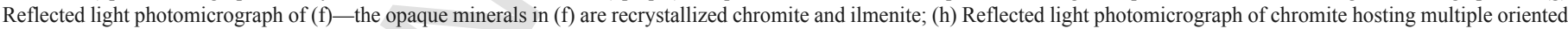

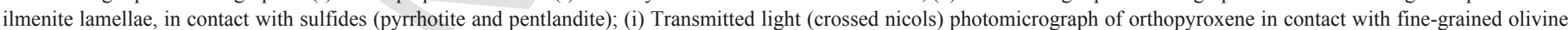

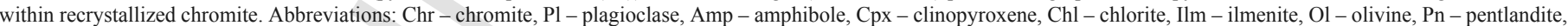
Po - pyrrhotite, Opx - orthopyroxene.

ited compositional variation at the grain scale. Clinopyroxene crystals (up to $3 \mathrm{~cm}$ ) show deformation revealed by folding of the cleavage planes. These crystals host many elongated oxide inclusions along the cleavage planes and show exsolution of orthopyroxene lamellae. The composition of clinopyroxene is relatively narrow, corresponding to the limit between diopside and augite $\left(\mathrm{En}_{44-49} \mathrm{Wo}_{48-46} \mathrm{Fs}_{8-5}\right)$, with $\mathrm{Mg} \#=0.85-0.92$ and high $\mathrm{TiO}_{2}(0.36-1.05$ wt.\%) (Appendix 5). Some clinopyroxene grains show rims with slightly different extinction angles (Fig. 4b) and higher diopside contents. 


\subsection{Metasomatized chromitite}

The interaction between the pegmatitic gabbro enriched in trace elements and the ordinary chromitite generated unusual mineral phases in the metasomatized chromitite. This type of rock shows strong variability in textures and modal mineralogy at the hand-sample and thin-section scales. Most samples show coarse granular textures with crystals up to $2 \mathrm{~cm}$ in length (Fig. 2e, f, 4c, d). The primary igneous-metasomatic phases are $\mathrm{Fe}^{3+}$-Ti-rich chromite, Ti-rich amphibole, orthopyroxene, olivine, $\mathrm{Mg}$-rich ilmenite, and $\mathrm{Fe}-\mathrm{Cu}-\mathrm{Ni}$ sulfides (Fig 4c, d). This assemblage experienced variable late overprinting that is attributed to ocean floor alteration/metamorphism, which produced the secondary serpentine-group minerals, chlorite, ferrian-chromite, magnetite, actinolite-tremolite, rutile, and titanite.

Metasomatized chromite forms generally subhedral crystals with sizes ranging between 0.5 and $2 \mathrm{~cm}$ (Fig. 4c-e). Locally, octahedral chromite crystals are cemented by sulfides. Chromite is usually associated with amphibole and ilmenite (Fig. 4f, g) and most chromite grains host abundant crystallographically-oriented ilmenite lamellae (Fig. 4h). Metasomatized chromite has higher $\mathrm{Cr} \#[\mathrm{Cr} /(\mathrm{Cr}+\mathrm{Al})](0.57$ - 0.70), higher $\mathrm{Fe}^{3+} \#\left[\mathrm{Fe}^{3+} /\left(\mathrm{Fe}^{3+}+\mathrm{Cr}+\mathrm{Al}\right)\right](0.10-0.30)$ and lower $\mathrm{Mg} \#\left[\mathrm{Mg} /\left(\mathrm{Mg}+\mathrm{Fe}^{2+}\right)\right](0.31$ - 0.53) than chromite from ordi- nary chromitites $\left(\mathrm{Cr} \#=0.44-0.54, \mathrm{Fe}^{3+} \#<0.05\right.$, and $\mathrm{Mg} \#=0.66-0.74$; see also Proenza et al., 2001). It is also enriched in $\mathrm{TiO}_{2}(1.02-4.34$ wt.\%), $\mathrm{Fe}^{3+}$ (up to calculated 21.5 wt. $\% \mathrm{Fe}_{2} \mathrm{O}_{3}$ ), $\mathrm{Fe}^{2+}$ (up to calculated 25.31 wt.\% FeO), and $\mathrm{V}_{2} \mathrm{O}_{3}$ (up to 0.7 wt.\%) (Fig. 5) (Appendix 6). Two types of metasomatized chromite can be distinguished (Fig. 5):

(I) Type I bears an intermediate composition between ordinary and metasomatized s.s. chromite (type II, see below) $(\mathrm{Cr} \#=0.57-$ $0.58, \mathrm{Fe}^{3+} \#=0.10-0.13$, and $\left.\mathrm{Mg} \#=0.51-0.53\right)$, which roughly corresponds to the "brecciated chromite ore" defined by Proenza et al. (2001).

(II) Type II (Cr\#=0.62-0.70, $\mathrm{Fe}^{3+} \#=0.19-0.30$, and $\left.\mathrm{Mg} \#=0.31-0.39\right)$ further interacted with the gabbroic dikes and corresponds to the "sulfide-rich chromite ore" (10-30 vol.\% Fe-Ni-Cu sulfides) of Proenza et al. (2001).

The change in composition from ordinary to type II metasomatized s.s. chromite is defined by an enrichment trend in $\mathrm{Cr} \#, \mathrm{Fe}^{3+} \#$, and $\mathrm{TiO}_{2}$ (Fig. 5). In type II metasomatized chromitite the sulfides are usually intergranular to (or forming rims around) chromite (Fig. 4d, h) and are mainly pyrrhotite, pentlandite, chalcopyrite and cubanite, with minor amounts of chalcocite and valleriite (Proenza et al., 2001).
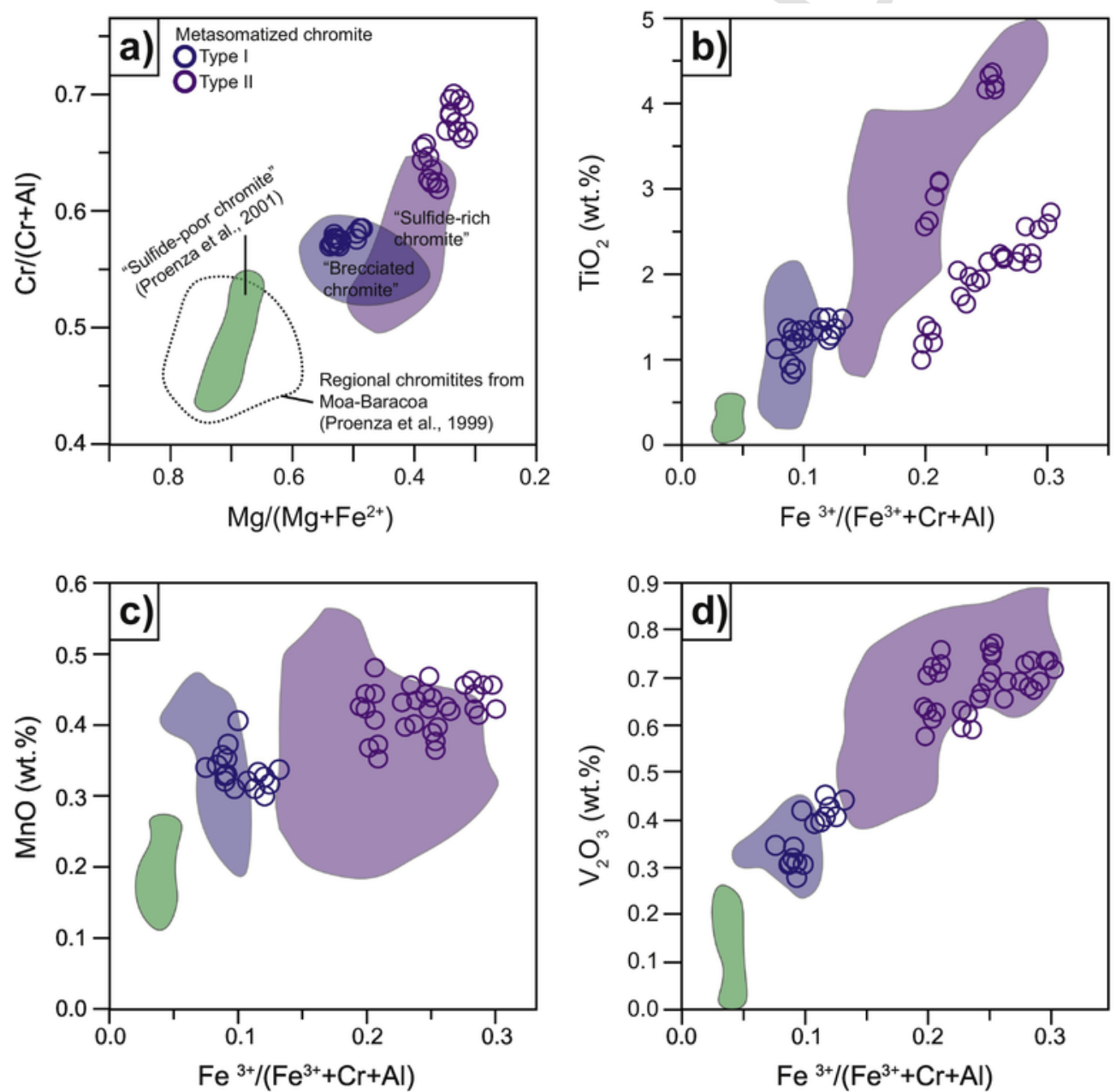

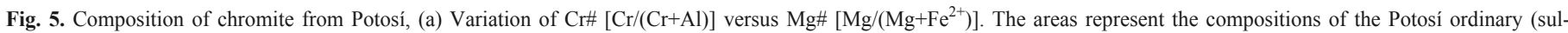

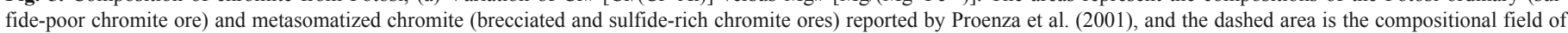
the chromitites from the Moa-Baracoa Massif (Proenza et al., 1999b); (b) $\mathrm{TiO}_{2}$ versus $\mathrm{Fe}^{3+} \#\left[\mathrm{Fe}^{3+} /\left(\mathrm{Fe}^{3+}+\mathrm{Cr}+\mathrm{Al}\right)\right]$; (c) $\mathrm{MnO}$ versus Fe ${ }^{3+} \#$; and (d) $\mathrm{V}_{2} \mathrm{O}_{3}$ versus $\mathrm{Fe}^{3+} \#$. 
Brown amphibole forms large crystals (up to $2 \mathrm{~cm}$ ) and coronas around the chromite (Fig. 4a, e). Large crystals usually host a myriad of elongated inclusions (up to $15 \mu \mathrm{m}$ long) of ilmenite, rutile and titanite following the cleavage planes (Fig. 4f, g). Amphibole composition (Fig. 6a-h) is Ti-rich with $\mathrm{TiO}_{2}$ ranging between 2.41 and 5.46 wt.\%, $\mathrm{Mg} \#$ between 0.82 and $0.94, \mathrm{Cl}$ up to 0.05 wt.\% and $\mathrm{F}$ up to 0.5 wt. \%, corresponding mainly to Ti-rich magnesio-hastingsite and, to a lesser extent, Ti-rich pargasite and ferri-kaersutite compositions (calculations following Locock, 2014 and the classification scheme of Hawthorne et al., 2012; Fig. 6a-b; Appendix 5).
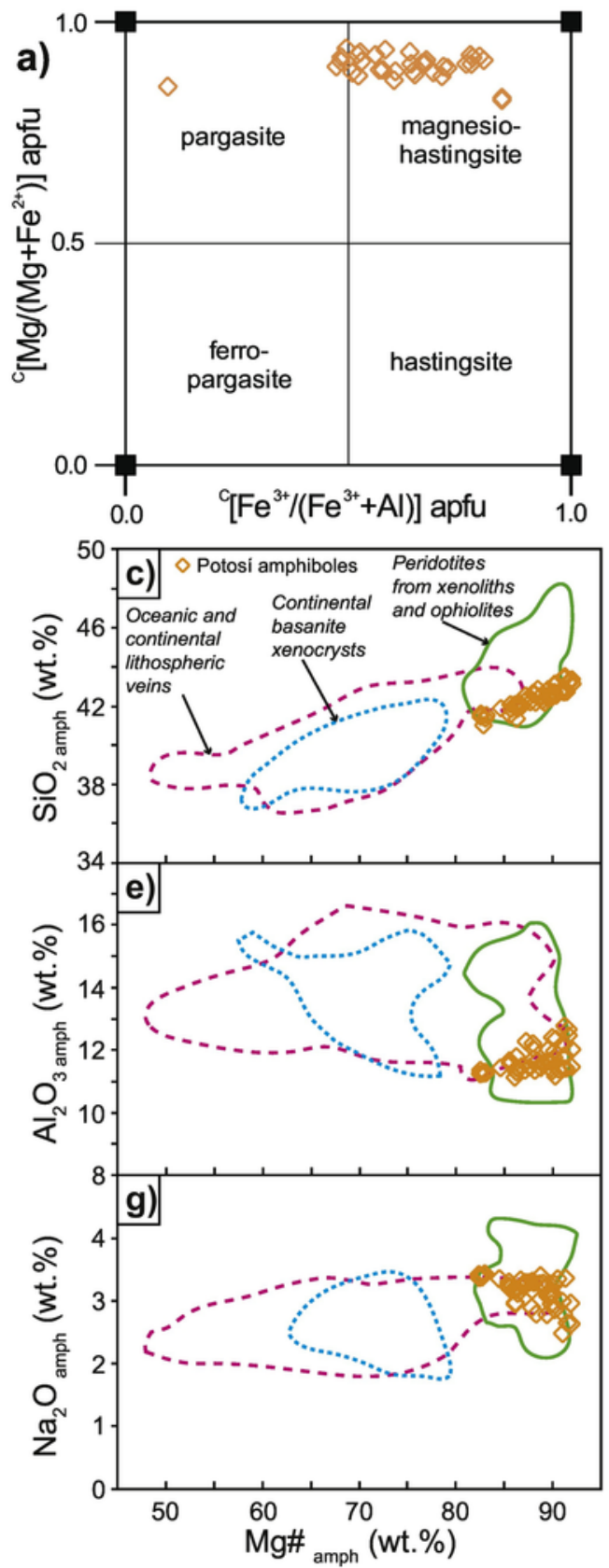

Orthopyroxene is not abundant and forms grains up to $3 \mathrm{~mm}$ that are generally free of inclusions and devoid of zoning with an ensta-

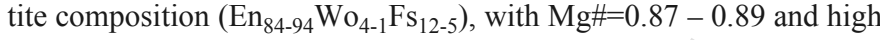
$\mathrm{TiO}_{2}$ contents $(0.23-0.47$ wt. $\%$, Appendix 5$)$. These orthopyroxenes are in contact with rare fine-grained $\mathrm{Fo}_{86-91}$ olivine (up to $200 \mu \mathrm{m}$ ) (Fig. 4i) with $\mathrm{NiO}$ ranging between 0.12 and 0.22 wt.\% (Appendix 5). The higher forsterite contents correspond to typical mantle olivine, including olivine from the regional Moa-Baracoa chromitites $\left(\mathrm{Fo}_{90-97}\right.$; Proenza et al., 1999b), while the lower forsterite values are closer to those of gabbroic intrusions $\left(\mathrm{Fo}_{74-82}\right.$; Marchesi et al., 2006
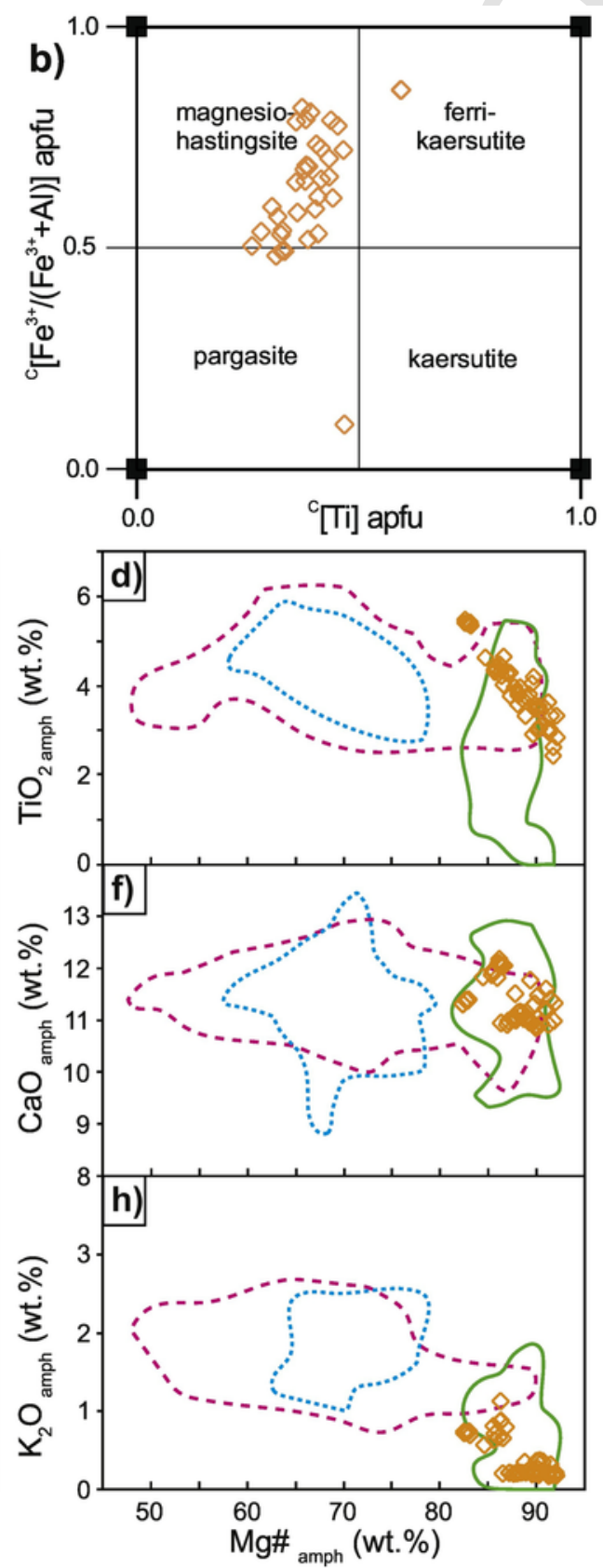

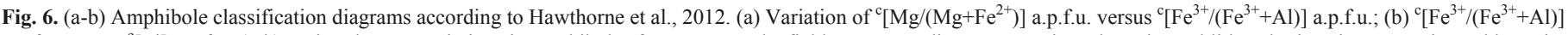

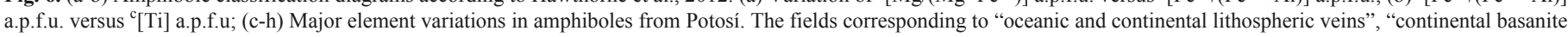

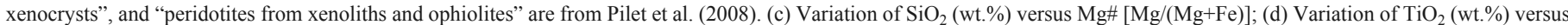

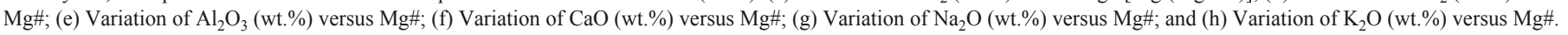


). Olivine crystals locally include elongated grains of oriented Cr-spinel and ilmenite.

Ilmenite forms subhedral to anhedral crystals (up to $1 \mathrm{~cm}$ ) located at the rims of (Fig. 4g), or within, chromite crystals (Fig. 7a, d, f, h) and forms oriented lamellae in chromite following its crystallographic orientation (Fig. 4h). The content in the geikielite component (Appendix 7) varies between 1 and $45 \mathrm{~mol}^{\circ} \mathrm{MgTiO}_{3}$ (averaging 26 mol\%) (Fig. 8a, b). Ilmenite grains are devoid of chemical zoning and compositional variations are independent of textural position, as illustrated by strikingly different geikielitic contents in adjacent grains of ilmenite (Fig. 8a, b).

Several mineral phases occur as inclusions within, or at the rims of, grains of ilmenite. The most abundant is apatite, forming euhedral to subhedral elongated crystals up to $500 \mu \mathrm{m}$ long (Fig. 9a, b) in contact with or included within ilmenite. Seldom, apatite crystals include sulfide inclusions (Fig. 9b). Apatite contains $0.85-1.52$ wt.\% F and $0.54-0.77$ wt. $\% \mathrm{Cl}$, with a $\mathrm{Cl} / \mathrm{F}$ (molar) ratio between 0.33 and 0.48 (Appendix 8). Relatively small (up to $500 \mu \mathrm{m}$ in length) ilmenite crystals in contact with chromite host accessory Zr-oxides (baddeleyite, zirconolite, and srilankite) (Fig. 7), whereas large ilmenite crystals (up to $0.5 \mathrm{~cm}$ long) in contact with silicates (Fig. 9) show zircon coronas. It is noteworthy that $\mathrm{Zr}$-oxides and zircon do not coexist surrounding, or within, a given ilmenite crystal.

$\mathrm{Zr}$ oxides form subhedral to anhedral elongated crystals with sizes ranging between 10 and $80 \mu \mathrm{m}$ long within ilmenite (Fig. 7). Occasionally, the $\mathrm{Zr}$ oxide inclusions have multiple mineral phases (e.g., baddeleyite and zirconolite or baddeleyite and srilankite; Fig. 7i). Baddeleyite crystals show Hf-enrichment $\left(\mathrm{HfO}_{2}\right.$ between 1.52 and 1.96 wt.\%) and low $\mathrm{Nb}, \mathrm{Nd}$, and $\mathrm{U}$ contents (up to 0.06 wt.\% $\mathrm{Nb}_{2} \mathrm{O}_{3}$, up to 0.06 wt. $\% \mathrm{Nd}_{2} \mathrm{O}_{3}$, up to 0.07 wt.\% $\mathrm{U}_{2} \mathrm{O}_{3}$ ) (Appendix 8). Zirconolite composition deviates from the ideal $\mathrm{CaZrTi}_{2} \mathrm{O}_{7}$ (Fig. 10a), with very low $\mathrm{U}$ and Th contents (Fig. 10b), relative enrichment in REE $\left(\mathrm{REE}_{2} \mathrm{O}_{3}=9.25-10.7 \mathrm{wt} . \%\right.$ ) (Fig. 10c) and containing exceptionally high $\mathrm{Y}$ (up to 11.06 wt.\% of $\mathrm{Y}_{2} \mathrm{O}_{3}$ ) (Appendix 9). The studied zirconolite contains the highest $\mathrm{Y}$ concentrations reported to date in terrestrial zirconolite and the observed dominant coupled substitution is: $2 \mathrm{Ca}^{2+}+$ $\mathrm{Ti}^{4+}=2(\mathrm{REE}, \mathrm{Y})^{3+}+(\mathrm{Fe}, \mathrm{Mg})^{2+}$ (Fig. 10d). Two compositional groups of zirconolite are observed with different degrees of coupled substitution (Fig. 10).

Zircon grains (up to $50 \mu \mathrm{m}$ ) usually form rims around large ilmenite crystals, clustering at the contact with silicates (Fig. 9a, d), and they may appear elongated following the rim of ilmenite (Fig. 9e-g). Generally, zircon coronas show granular textures (Fig. 9f) and include ilmenite grains in between. Zircon is devoid of zoning (Appendices 10 and 11) with $\mathrm{HfO}_{2}$ content ranging between 0.17 and 1.54 wt.\%, which is within the range of abundance for natural zircon $(0.5-5$ wt.\%; Belousova et al., 2002). These zircon coronas generally remain unaltered during alteration of ilmenite to rutile and titanite (Fig. 9h, i). Occasionally, zircon is replaced by an aggregate of fine-grained baddeleyite (secondary baddeleyite) together with Mg-Al silicates (Fig. $9 \mathrm{c})$. Figure 11 summarizes the main petrographic features and mineral relations observed in the metasomatized chromitite in Potosí.

\subsection{Mineral trace element compositions}

Minerals from the metasomatized chromitite show relatively unusual trace element distribution and patterns (Appendix 12). Trace elements of chromite normalized to MORB chromite (Fig. 12a) show a positive anomaly in $\mathrm{Ti}$ and negative anomaly in $\mathrm{Ni}$, which is not typical in Al-rich ophiolitic chromitites of the Moa-Baracoa massif, usually displaying relatively flat patterns (e.g., Colás et al., 2014). The chondrite-normalized REE patterns of Ti-rich amphibole are characterized by LREE depletion, nearly flat HREE and negative
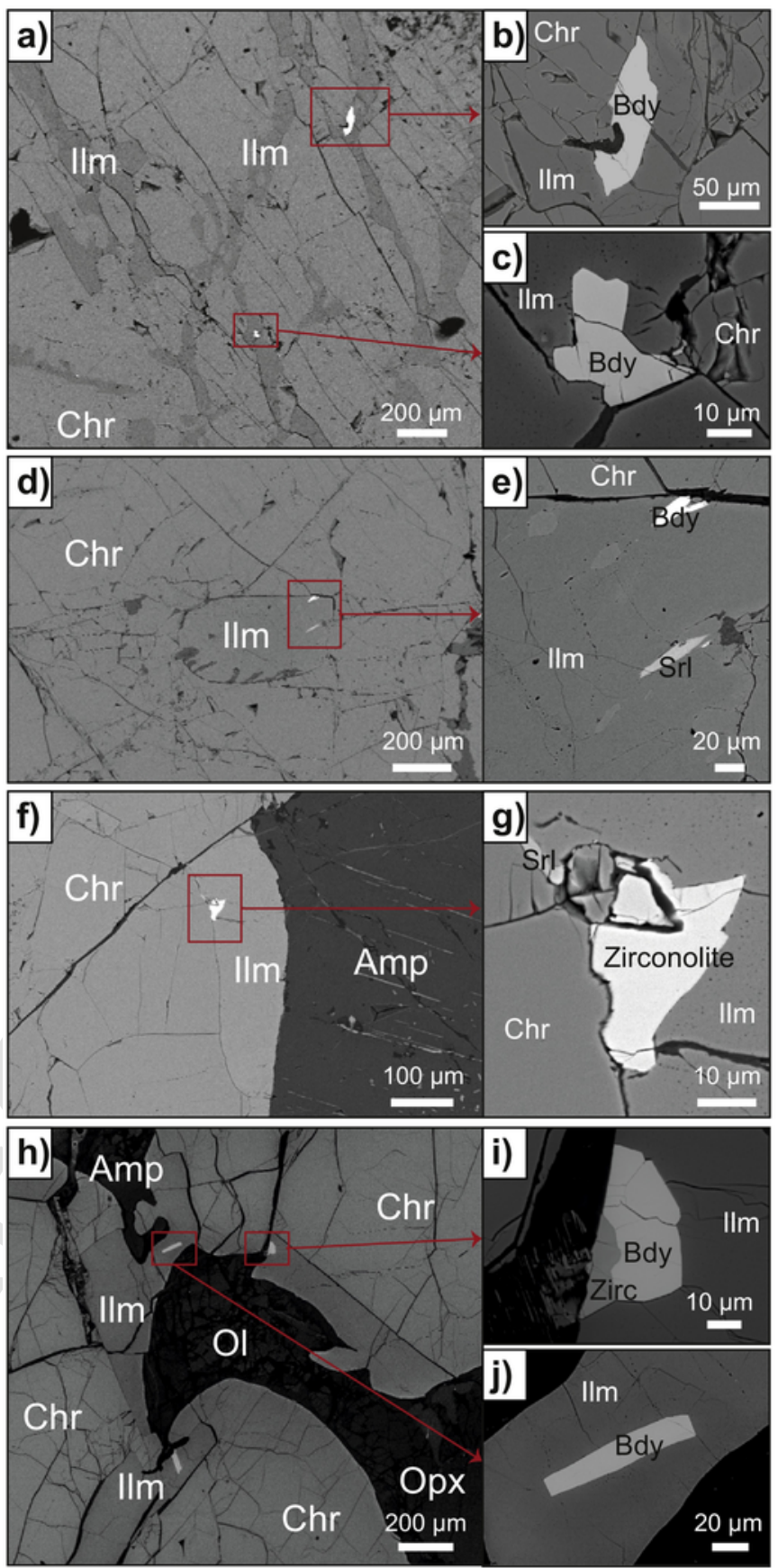

Fig. 7. Backscattered electron images of: (a) Elongated ilmenite crystals within chromite. Note the bright inclusions within ilmenite that correspond to Zr-bearing oxides; (b) Zoom of (a) showing a baddeleyite inclusion within ilmenite in contact with chromite; (c) Second zoom of (a) showing a baddeleyite inclusion within ilmenite in contact with chromite; (d) Ilmenite subrounded crystal hosted in chromite; (e) Zoom of (d) showing elongated inclusions of baddeleyite and probably srilankite within ilmenite; (f) Ilmenite crystal at the border of chromite; (g) Zoom of (f) showing a zirconolite inclusion with minor srilankite in the upper part, hosted in ilmenite in the contact with chromite; (h) Ilmenite crystals in equilibrium with chromite hosting elongated baddeleyite crystals. Note that the interstitial silicate minerals are mainly olivine, with minor orthopyroxene and amphibole; (i) Zoom of (h) showing an inclusion of baddeleyite together with zirconolite; and (j) Zoom of (h) showing an elongated tabular baddeleyite inclusion within ilmenite. Abbreviations: $\mathrm{Chr}$ - chromite, Ilm - ilmenite, Bdy - baddeleyite, Srl - srilankite, Amp - amphibole, Ol - olivine, Opx - orthopyroxene, Zirc zirconolite. 

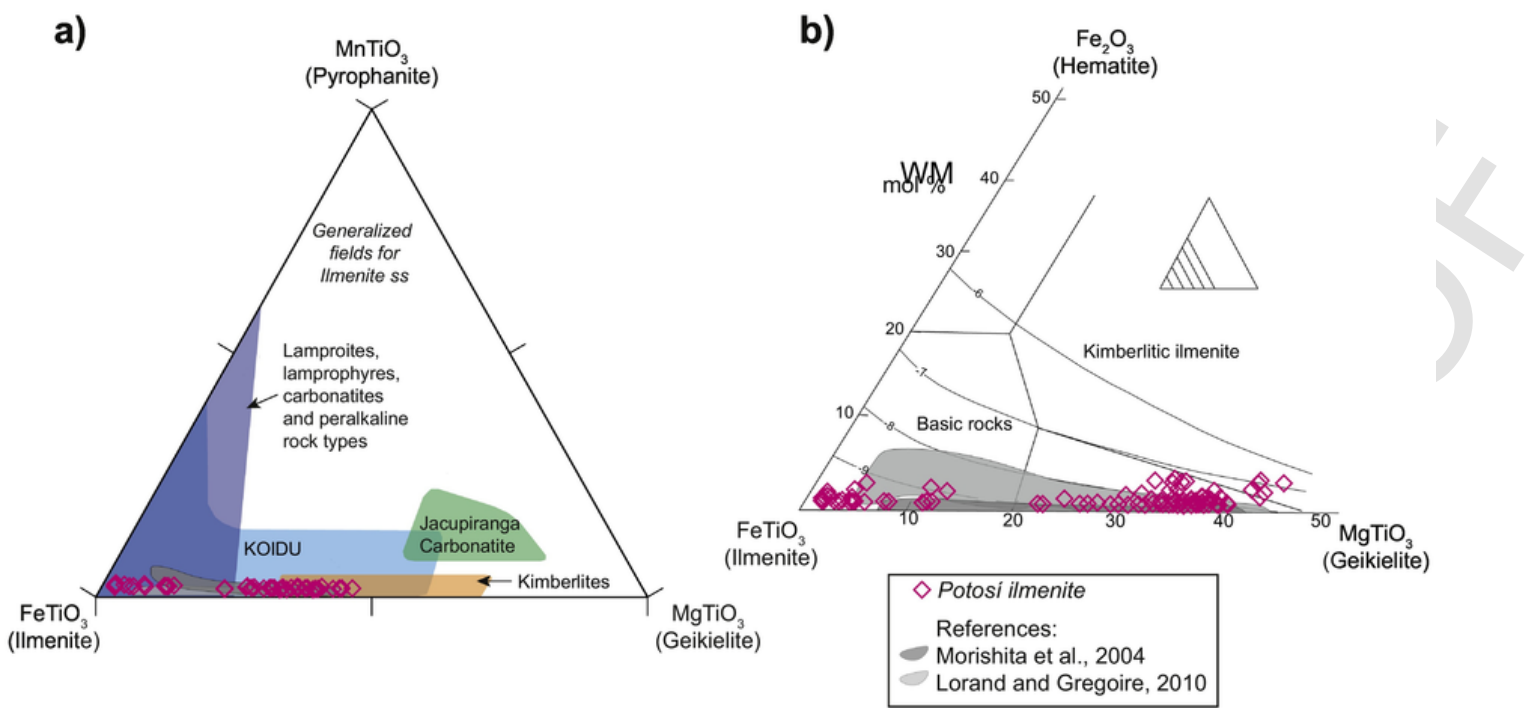

Fig. 8. (a) Ilmenite composition in terms of the pyrophanite $\left(\mathrm{MnTiO}_{3}\right)$-ilmenite $\left(\mathrm{FeTiO}_{3}\right)$-hematite $\left(\mathrm{Fe}_{2} \mathrm{O}_{3}\right)$ endmembers. The compositional fields are from Tompkins and Haggerty (1985) and the shaded areas correspond to Morishita et al. (2004) in dark grey and Lorand and Gregoire (2010) in light grey; and (b) Ilmenite composition in terms of the hematite $\left(\mathrm{Fe}_{2} \mathrm{O}_{3}\right)$-ilmenite $\left(\mathrm{FeTiO}_{3}\right)$-hematite $\left(\mathrm{Fe}_{2} \mathrm{O}_{3}\right)$ endmembers. Fields for kimberlitic ilmenites and basic rocks are from Mitchell (1977), the shaded areas correspond to Morishita et al. (2004) in dark grey and Lorand and Gregoire (2010) in light grey.

Eu anomalies (Fig. 12b), being similar in shape to (but more enriched than) associated clinopyroxene (Fig. 12c). Clinopyroxene shows two characteristic REE patterns corresponding to the cores and rims of grains. Clinopyroxene cores are particularly depleted in LREE and show strong fractionation from HREE to LREE (Fig. 12c), whereas clinopyroxene rims are characterized by higher trace element contents and larger negative Eu anomalies (Fig. 12c), with patterns depleted in LREE and a flat segment from MREE to HREE. Similar to clinopyroxene rims, orthopyroxene REE patterns (Fig. 12d) show strong REE fractionation, with a positive slope from LREE to HREE with negative $\mathrm{Eu}$ anomalies, but concentrations are one order of magnitude higher and the Eu negative anomaly is stronger.

Ilmenite trace element patterns (Fig. 12e) show positive anomalies in $\mathrm{Nb}$ and $\mathrm{Ta}$ and strong negative anomalies in Ni. Apatite shows REE patterns with a negative slope from LREE to HREE and slight Eu negative anomalies (Fig. 12f). The main substitution of $\mathrm{Ca}$ in the apatite structure is by $\mathrm{Y}$ and REE (REE $+\mathrm{Y}=161-405 \mathrm{ppm})$.

Zircon shows very low $\mathrm{U}$ (up to $54 \mathrm{ppm}$ ), $\mathrm{Pb}$ (up to $5 \mathrm{ppm}$ ), and Th contents (up to $6 \mathrm{ppm}$ ) (Appendix 12). Its crystallization temperature has been estimated using the Ti-in-zircon thermometer (Ferry and Watson, 2007; Watson et al., 2006), but due to the intimate intergrowth of zircon and ilmenite, the Ti content in nominally clean zircon reaches high values ( $>4320 \mathrm{ppm})$ thus resulting in extremely high apparent crystallization temperatures that are not reasonable. The analyzed zircon grains have very pronounced $\mathrm{Ce} / \mathrm{Ce} *(25-218)$ and the chondrite-normalized REE patterns (Fig. $12 \mathrm{~g}$ ) show a positive steep slope from LREE to HREE with positive Ce and negative Eu anomalies. The chondrite-normalized REE patterns of zirconolite show positive slopes from LREE to MREE and flat segments from MREE to HREE (Fig. 12h) with negative Eu anomalies.

\subsection{U/Pb dating}

Zircon grains forming coronas around ilmenite crystals are extremely depleted in $\mathrm{U}$ and $\mathrm{Pb}$, especially in $\mathrm{Pb}^{207}$, making it difficult to obtain a reliable date. The analyses yielded an average age $(n=43)$ of $369 \pm 24 \mathrm{Ma}$ and a secondary cluster at $57 \pm 17 \mathrm{Ma}$. On the other hand, analyses on 7 baddeleyite grains yielded one concordant age and 6 discordant but equivalent ages of $134.4 \pm 14$ Ma (Appendices 4 and 13).

\section{Discussion}

\subsection{Meaning of the Fe-Ti-Zr minerals in the chromitite: contrasting} literature data

We report metasomatic interaction of gabbroic melts with the chromitite located in the MTZ of the Moa-Baracoa ophiolite resulting in the metasomatism of pre-existing chromitite and the formation of a new exotic assemblage of Fe-Ti-Zr minerals. As noted above, the newly-formed mineral assemblage includes Ti-rich amphibole, Mg-rich ilmenite, $\mathrm{Zr}$ oxides, and zircon, and has characteristics that resemble those from SCLM settings, kimberlites, carbonatites or alkaline basalts (e.g., Lorand and Gregoire, 2010). Similar amphibole, usually K-rich, is typical of the MARID (mica-amphibole-rutile-ilmenite-diopside) assemblage in mantle xenoliths from kimberlites (e.g., Dawson and Smith, 1977; Fitzpayne et al., 2018; Grégoire et al., 2002), whereas Mg-rich ilmenite (Fig. 8) is also typical from kimberlites (e.g., Xu et al., 2018). Mg-ilmenite compositions have also been described in megacrysts in alkaline basalts from Algeria (Leblanc et al., 1982), in zirconolite-bearing ultrapotassic veins in mantle xenoliths from the Mt. Melbourne volcanic field in Antarctica (Hornig and Wörner, 1991), in some metasomatized peridotite xenoliths and peridotite massifs (Bodinier et al., 1996; Ionov et al., 1999), as well as in the amphibole-rich veins in the Lherz Massif (Lorand and Gregoire, 2010). The studied ilmenite in Potosí contains particularly low trivalent iron and is devoid of hematite exsolution, with compositions very similar to the ilmenite found in the amphibole veins of the Lherz Massif (Lorand and Gregoire, 2010) both in major (Fig. 8) and trace elements (Fig. 12e). In addition, the chromite trace elements (Fig. 12a) show similarities with accessory chromite from kimberlites and picrites (Yao, 1999).

Zirconolite is a frequent mineral in carbonatites, kimberlites, ultrapotassic metasomatic veins, skarns, as well as many others rock-forming settings (e.g., Williams and Gieré, 1996; Fig. 10). However, the only known occurrence of zirconolite in chromitite is in the Finero SCLM peridotites (Zaccarini et al., 2004). Most zirconolite re- 

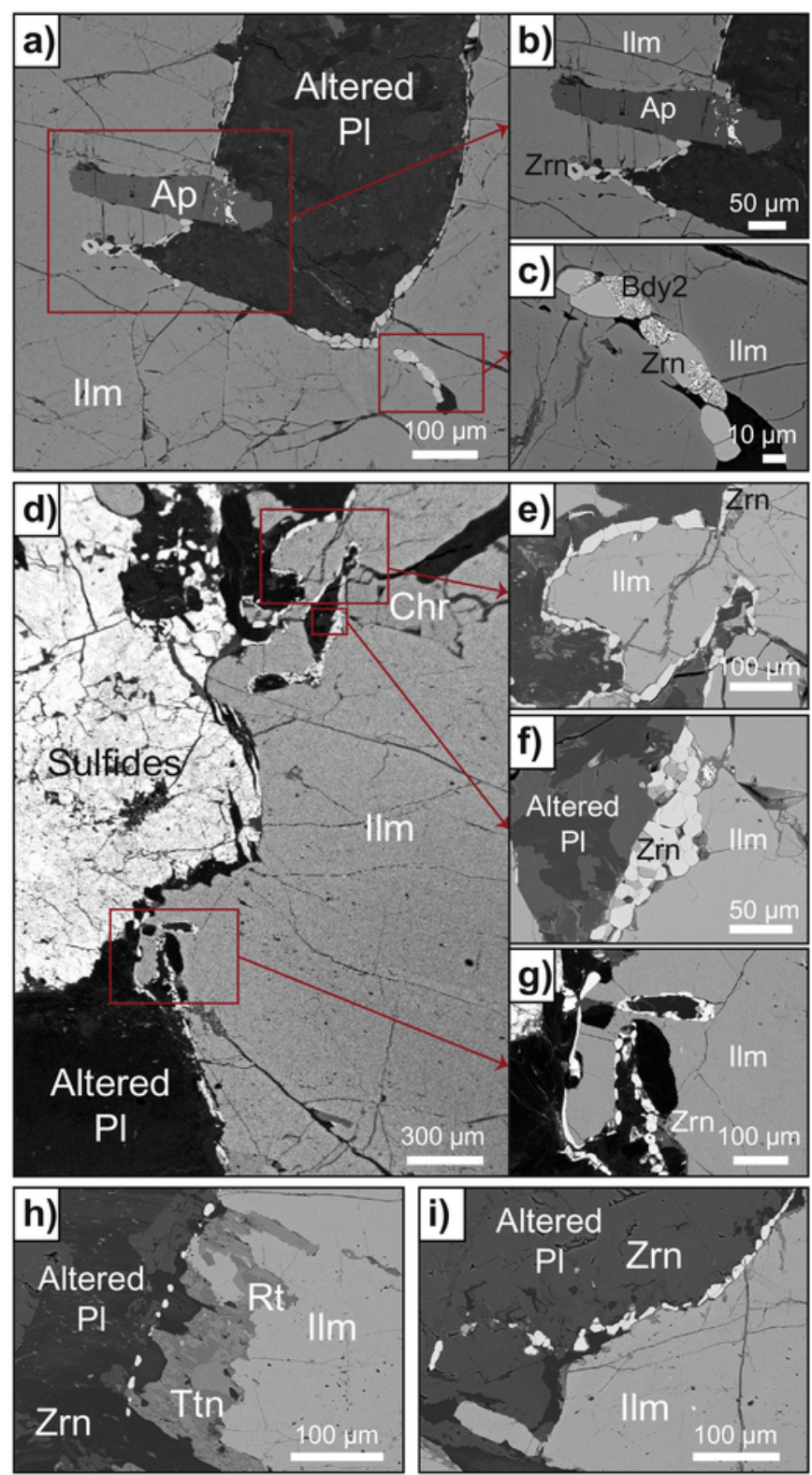

Fig. 9. Backscattered electron images of: (a) Zircon corona around ilmenite in contact with altered plagioclase. Ilmenite hosts a large apatite crystal; (b) Zoom of (a) showing a detail of the apatite crystal including $\mathrm{Cu}$ sulfides, and the zircon corona; (c) Zoom of (a) showing alteration of granular zircon to secondary baddeleyite mixed with silicates; (d) Large ilmenite crystal with zircon coronas along the ilmenite borders in contact with altered silicates. Note that in the region where ilmenite is in contact with sulfides, zircons are not present; (e) Zoom of (d) showing details of zircon grains surrounding ilmenite. Note the elongated shape of zircons; (f) Zoom of (d) showing the granular texture of zircons forming the coronas. Note the presence of interstitial ilmenite grains within these of zircons and that zircon grains are in contact with altered plagioclase; $(\mathrm{g})$ Zoom of (d) showing detail of the zircon rims; (h) Ilmenite altered to rutile and titanite. The zircon corona around the primary ilmenite crystal remains immobile and unaltered during ilmenite replacement; and (i) Zircon corona around ilmenite defines ilmenite grain boundaries previous to alteration. Abbreviations: Ap - apatite, $\mathrm{Pl}$ - plagioclase, Ilm ilmenite, Zrn - zircon, Bdy2 - secondary baddeleyite, Chr - chromite, Rt - rutile, Ttn titanite.

ported in the literature cluster in a similar compositional field (Fig. 10), but the Potosí zirconolite plots close to zirconolite from potassic lavas (De Hoog and Van Bergen, 2000) and lunar basalts (Rasmussen et al., 2008; Williams and Gieré, 1996). Actually, Potosí zirconolite contains the highest $\mathrm{Y}_{2} \mathrm{O}_{3}$ content described to date in terrestrial zir- conolite (up to 11.06 wt. $\% \mathrm{Y}_{2} \mathrm{O}_{3}$ ) and the REE contents are also high (up to 10.7 wt.\% $\mathrm{REE}_{2} \mathrm{O}_{3}$ ), only comparable with contents in zirconolite from lunar basalts (Rasmussen et al., 2008; Williams and Gieré, 1996). The studied zirconolite contains low amounts of actinides (U, Th) strongly differing from the Finero chromitites' zirconolite (Zaccarini et al., 2004).

It is a great challenge to reconcile the different settings that this complex mineral assemblage may suggest, including SCLM, kimberlites, carbonatites, alkaline basalts, and those of lunar origin, in the suprasubduction zone ophiolite setting of Moa-Baracoa. In this context, it is essential to consider a simple integrated model that can be conceptualized in a suboceanic mantle setting as described hereafter.

\subsection{Formation of the HFSE-bearing assemblage}

The clinopyroxene cores crystallized at an early stage and show trace element compositions (Fig. 12c; Appendix 12) similar to those from gabbros sampled from the Mid-Atlantic Ridge (e.g., Coogan et al., 2000). This was followed by the crystallization of plagioclase (that caused depletion in $\mathrm{Eu}$ ) and the crystallization of the clinopyroxene REE-enriched rims (Fig. 12c) and the orthopyroxene (cf. Bodinier et al., 2008; Drouin et al., 2009; Meyer et al., 1989). During the process, the evolving liquid exsolved a sulfide liquid (Fig. 4d, 11), while relict olivine from the chromitite protolith changed their composition ( $\mathrm{Fo}<$ 90; Appendix 5), chromite recrystallized (Fig. 5; Cr\# $=0.57-0.70$, $\mathrm{Fe}^{3+} \#=0.10-0.30$, and $\left.\mathrm{Mg} \#=0.31-0.53\right)$, and the HFSE-bearing mineral phases (explained hereafter) crystallized.

\subsubsection{Ti-rich amphibole}

The chemical composition of amphibole (Fig. 6; Appendix 5), characterized by high $\mathrm{Ti}$, relatively high $\mathrm{F}$, and low $\mathrm{Cl}$ contents indicates a magmatic origin (Coogan et al., 2001; Vanko and Stakes, 1991), though it is texturally late (coronas around plagioclase and clinopyroxene, Fig. 4a, e, and larger interstitial crystals, Fig. 4f, g). Similar compositions are found in oceanic environments, such as gabbros recovered from the Mid Atlantic Ridge (e.g., Coogan et al., 2000, 2001; Cortesogno et al., 2000; Gillis et al., 1993; Koepke et al., 2005) and in olivine-bearing gabbros from the Northern Italy ophiolites (e.g., Tribuzio et al., 1995, 2000, 2014), interpreted as the result of interaction at high temperature with percolating $\mathrm{H}_{2} \mathrm{O}$-rich igneous agents (e.g., Tribuzio et al., 2000). However, these differ with the compositions of amphibole from oceanic veins (compilation by Pilet et al., 2011).

Ti-rich amphibole in oceanic rocks is also typical of low-pressure ( $<4$ kbar) high temperature (ca. $700-800^{\circ} \mathrm{C}$ ) ocean floor metamorphism of mafic rocks, as recorded in tectonic blocks of amphibolite (former fore-arc basaltic dykes intruding residual peridotites) from serpentinite mélanges of eastern Cuba (Lázaro et al., 2016). However, amphibole formed during oceanic metamorphism is typically characterized by a high-Cl content (e.g., Currin et al., 2018; Gillis et al., 1993; Gillis and Meyer, 2001; Gillis and Thompson, 1993; Pertsev et al., 2015; Prichard and Cann, 1982; Vanko, 1986), yet the $\mathrm{Cl}$ content of the studied amphiboles is low $(<0.05$ wt. $\% \mathrm{Cl},<0.016 \mathrm{Cl}$ per 23 $\mathrm{O}$ in the amphibole formula), thus dismissing a hydrothermal/metamorphic alteration at the oceanic stage. Furthermore, even if the temperature conditions of formation of Ti-rich amphibole in the studied case cannot be accurately established due to the open-system behavior during metasomatism and the lack of thermodynamic equilibrium in the studied assemblage, the Ti-Al-calcic amphibole thermobarometer of Ernst and Liu (1998) for rutile/titanite/ilmenite-saturated MORB rocks point to magmatic conditions for amphibole formation (ca. 1075 ${ }^{\circ} \mathrm{C}, 1 \mathrm{kbar}$; ca. $925^{\circ} \mathrm{C}$ at $5 \mathrm{kbar}$ ). Fractional crystallization of a Ti-rich evolved crystallizing/reacting metasomatic melt can satisfactorily explain the enrichment in HREE of amphibole (Fig. 12b; 

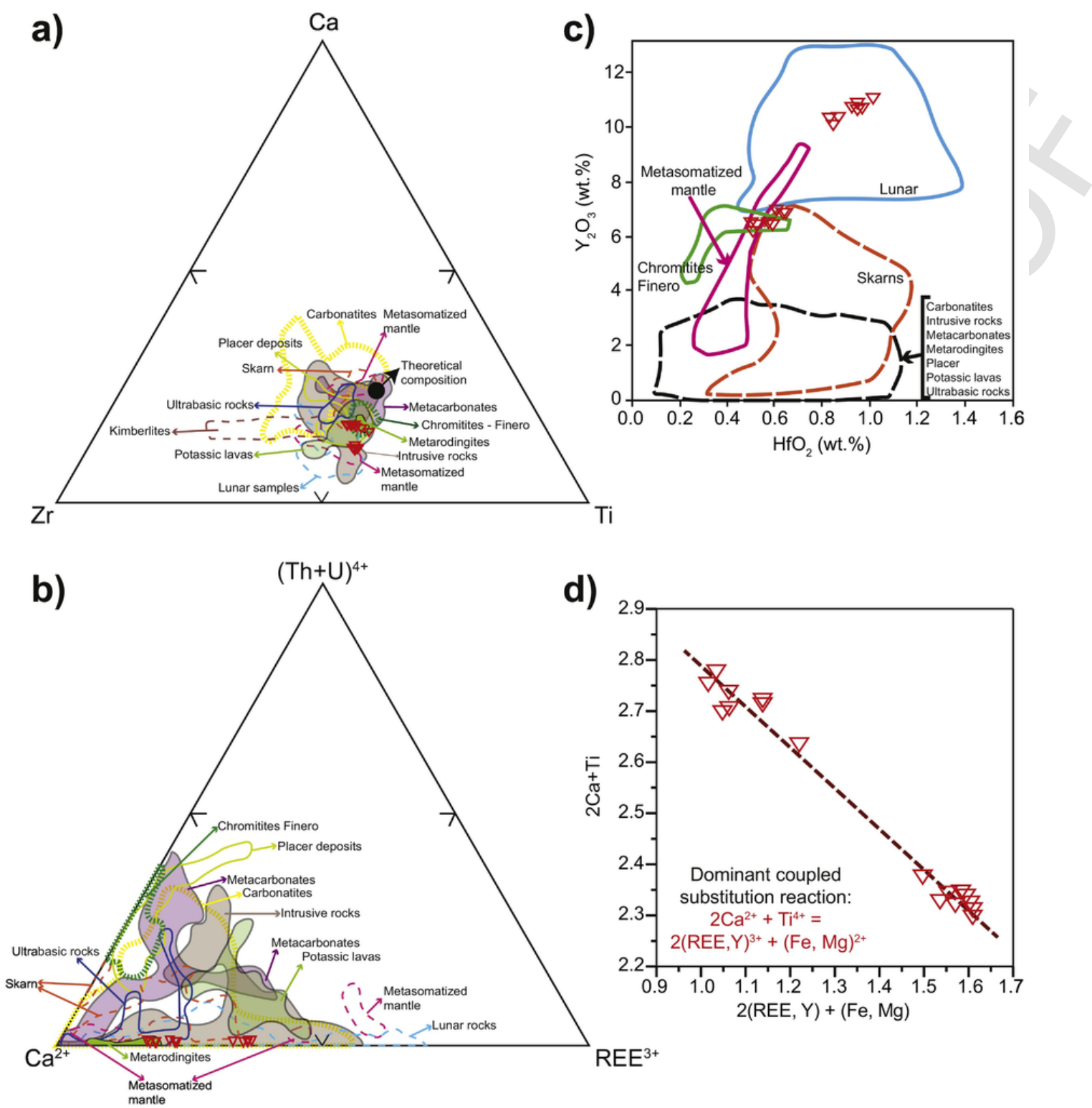

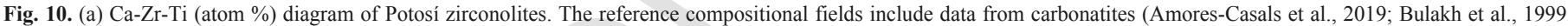

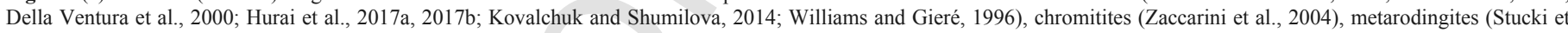

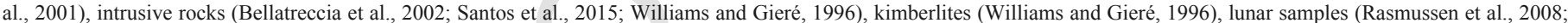

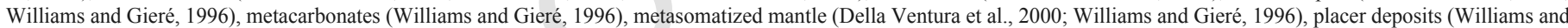

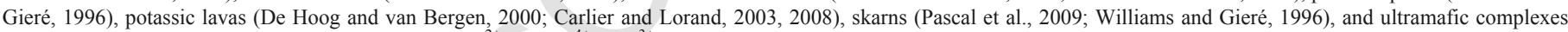

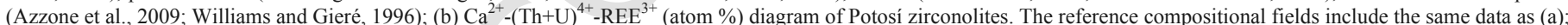

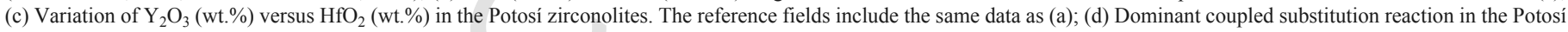
zirconolite. The diagram shows variation of [2Ca+Ti] versus [2( $\mathrm{REE}+\mathrm{Y})+(\mathrm{Fe}+\mathrm{Mg})]$.

Coogan et al., 2000). On the other hand, the trace-element composition of studied amphibole plots in the suprasubduction environment (Fig. 13; Coltorti et al., 2007), in agreement with the geodynamic position of the studied ophiolitic chromitites in a back-arc position (Proenza et al., 1999b).

\subsubsection{Mg-rich ilmenite}

Ilmenite probably crystallized during or just right after the formation of amphibole as a result of Fe-Ti saturation of the melt, as indicated by the textural positions of recrystallized chromite, ilmenite, and Ti-rich amphibole. Even though Mg-rich ilmenite is scarce in basaltic rocks of the oceanic lithosphere, it has been observed in sri- lankite-bearing gabbroic veins that crosscut oceanic peridotites (Morishita et al., 2004).

Since ilmenite appears on the liquidus of strongly fractionated high Fe-Ti melts (Clague et al., 1981; Dick et al., 2000; Juster et al., 1989; Morishita et al., 2004 and references therein), extreme differentiation of a percolating MORB-type melt during its ascent within the uppermost mantle may be needed (c.f., Morishita et al., 2004). However, Mg-rich ilmenite cannot simply form by fractional crystallization of basaltic liquid, because $\mathrm{Mg}$ and $\mathrm{Ti}$ have opposite behaviors during this process. Following Lorand and Gregoire (2010), the interaction of an evolved (Fe-) Ti-rich melt with host Ol-bearing chromitite is necessary to explain the observed decrease in $\mathrm{Mg}$ in metasoma- 


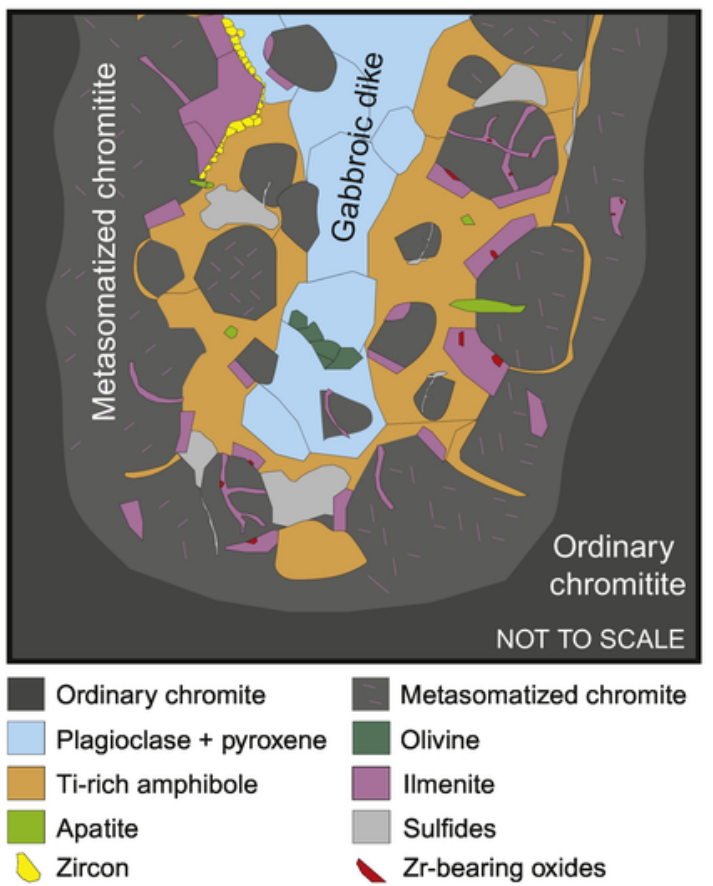

Fig. 11. Schematic relations between the observed mineral assemblage in the metasomatized chromitite, located at the interaction zone between the gabbroic dikes and the ordinary chromitite.

tized/recrystallized chromite and olivine and the corresponding increase in $\mathrm{Mg}$ in the crystallizing melt. Furthermore, preferential uptake of $\mathrm{Zr}$ (and Hf) by Ti-rich amphibole (e.g., Tiepolo et al., 2001) causes enrichment in $\mathrm{Nb}$ (and $\mathrm{Ta}$ ) in the residual melt, explaining the positive anomalies in $\mathrm{Nb}$ and $\mathrm{Ta}$ of the Potosí ilmenites that crystallized during or shortly after precipitation of Ti-rich amphibole.

\subsubsection{Apatite}

An increase in $\mathrm{P}$ content during the magmatic/metasomatic evolution of the differentiated gabbroic melt explains crystallization of apatite in contact with, or as inclusions within, ilmenite. The $\mathrm{Cl}$ content in apatite is within the range of normal apatite from gabbros (Zhang et al., 2017), while the F-rich component of the Potosí apatite indicates magmatic crystallization from an igneous silicate melt (O'Reilly and Griffin, 2000), strengthening the idea that seawater-derived fluids did not participate in the metasomatic process of the Potosí chromitite. However, the trace elements in apatite are one order of magnitude depleted compared to typical MORB apatite (Mao et al., 2016) and ophiolitic Fe-gabbro apatite (Tribuzio et al., 2000), indicating a late formation of this mineral in the metasomatic process.

\subsubsection{Zr minerals}

\subsubsection{Zr oxides: zirconolite, baddeleyite, and srilankite}

The observed textures, with simple and multiple (e.g., baddeleyite and zirconolite or baddeleyite and srilankite; Fig. 7) Zr oxides located within and adjacent to crystal borders of ilmenite hosted within large chromite grains (up to $5 \mathrm{~mm}$ ), suggest exsolution of $\mathrm{Zr}$ oxides from ilmenite (Fig. 7). Direct exchange of $\mathrm{Zr}^{4+}$ for $\mathrm{Ti}^{4+}$ is possible within the structure of ilmenite (Fujimaki et al., 1984; Jang and Naslund, 2003; McCallum and Charette, 1978; McKay et al., 1986; Morisset and Scoates, 2008; Nakamura et al., 1986; Taylor and McCallister, 1972). Though the amount of $\mathrm{Zr}$ in ilmenite is very low (up to 79 ppm; Appendix 12), we consider that the exsolution explains the tex- tural relations of $\mathrm{Zr}$ oxides, as for similar baddeleyite lamellae/blebs occurring within ilmenite from layered intrusions (Barkov et al., 1995; Heaman and LeCheminant, 1993; Naslund, 1987) and mafic granulite/ amphibolite (Bingen et al., 2001). A simultaneous oxidation process, as proposed by Naslund (1987) and Bingen et al. (2001), is not evident in Potosí as far as Mg-ilmenite contains a limited amount of trivalent $\mathrm{Fe}$ and lacks hematite exsolutions. A second generation of sheet-like baddeleyite, together with $\mathrm{Mg}$-Al silicates, crystallized after zircon in Potosí (Fig. 9c). Similar textures were reported by Morisset and Scoates (2008), where baddeleyite forms along sealed fractures within zircon and at zircon grain rims. Zirconolite and srilankite likely formed by an exsolution mechanism similar to baddeleyite however it depended on the availability of $\mathrm{Ca}$ and REE, which was provided by the evolved melt and/or apatite that also formed in contact with ilmenite. Thus, zirconolite would concentrate incompatible REE $+\mathrm{Y}$ of the late magmatic liquids/fluids.

\subsubsection{Zircon}

For many Fe-Ti oxide gabbros, zircon formed from volumetrically small, late-stage, fractionated, Zr-enriched interstitial melt pockets (Scoates and Chamberlain, 1995; Grimes et al., 2009; Beckman et al., 2017; but see also Pietranik et al., 2017, and references therein, for formation of zircon slightly above the wet basaltic solidus after fluid-fluxed partial melting of oceanic gabbros). Zircon occurs in Cuban ophiolitic gabbros and chromitites as magmatic (neoformed) and xenocrystic grains inherited from subducted sedimentary rocks (Proenza et al., 2018; Rojas-Agramonte et al., 2016). However, the studied zircon grains in Potosí are clearly not magmatic s.s. nor xenocrystic, but rather formed in situ during metasomatic interaction of chromitite with gabbroic melts, as indicated by textural relations.

Zircon coronas around ilmenite suggest high temperature $\mathrm{Zr}$ diffusion in ilmenite (exsolution) and subsequent reaction along grain boundaries under supersolidus to subsolidus conditions following ilmenite crystallization (Morisset and Scoates, 2008). As indicated above, $\mathrm{Zr}$ is highly compatible within the ilmenite structure and this mineral is usually considered as one potential source of $\mathrm{Zr}$ for zircon formation (Bea et al., 2006; Charlier et al., 2007; Morisset and Scoates, 2008; Sláma et al., 2007). The latter authors demonstrated that a reasonable concentration of $\mathrm{Zr}$ in ilmenite $(345-568 \mathrm{ppm}$ $\mathrm{Zr}$ initial concentration) accounts for the observed amount of zircon formed at the rims of ilmenite in mafic plutonic rocks of Proterozoic anorthosite suites. Furthermore, the studied zircon crystals have very low $\mathrm{U}$ and $\mathrm{Pb}$ contents, consistent with derivation from ilmenite (Morisset and Scoates, 2008; Zack and Brumm, 1998). Formation of zircon after baddeleyite exsolutions in the presence of silica, as proposed by Beckman et al. (2017), cannot be considered here because the observed relationship involves secondary growth of baddeleyite after replacement of granular zircon grains, and the presence of ilmenite interstitial to the granular zircon grains of the coronas is consistent with direct formation of zircon after ilmenite. In this process, silica would be provided by the adjacent silicates and/or the residual melt.

A metamorphic origin for zircon after high-pressure and/or temperature reactions (e.g., Austrheim et al., 2008; Beckman et al., 2014, 2017; Bingen et al., 2001; Kovaleva and Klötzli, 2017; Söderlund et al., 2004) is not considered here due to the lack of evidence for solid-state metamorphic transformation in the studied rocks. Likewise, a hydrothermal origin, similar to the zircons hosted in sealed fractures within chromitites introduced via a network of high-T fluids emanating from gabbroic dikes (Kapsiotis et al., 2016), is also discarded because of the low $\mathrm{HfO}_{2}$ content of the Potosí zircons ( $<1.54$ wt.\%; Appendix 11) and the HREE enrichment relative to LREE (Fig. 12g). Hydrothermal zircon usually has high $\mathrm{HfO}_{2}$ content (3.4 to 4.9 wt.\%) (Hoskin and Schaltegger, 2003), high U (550 - 13,000 ppm) and 

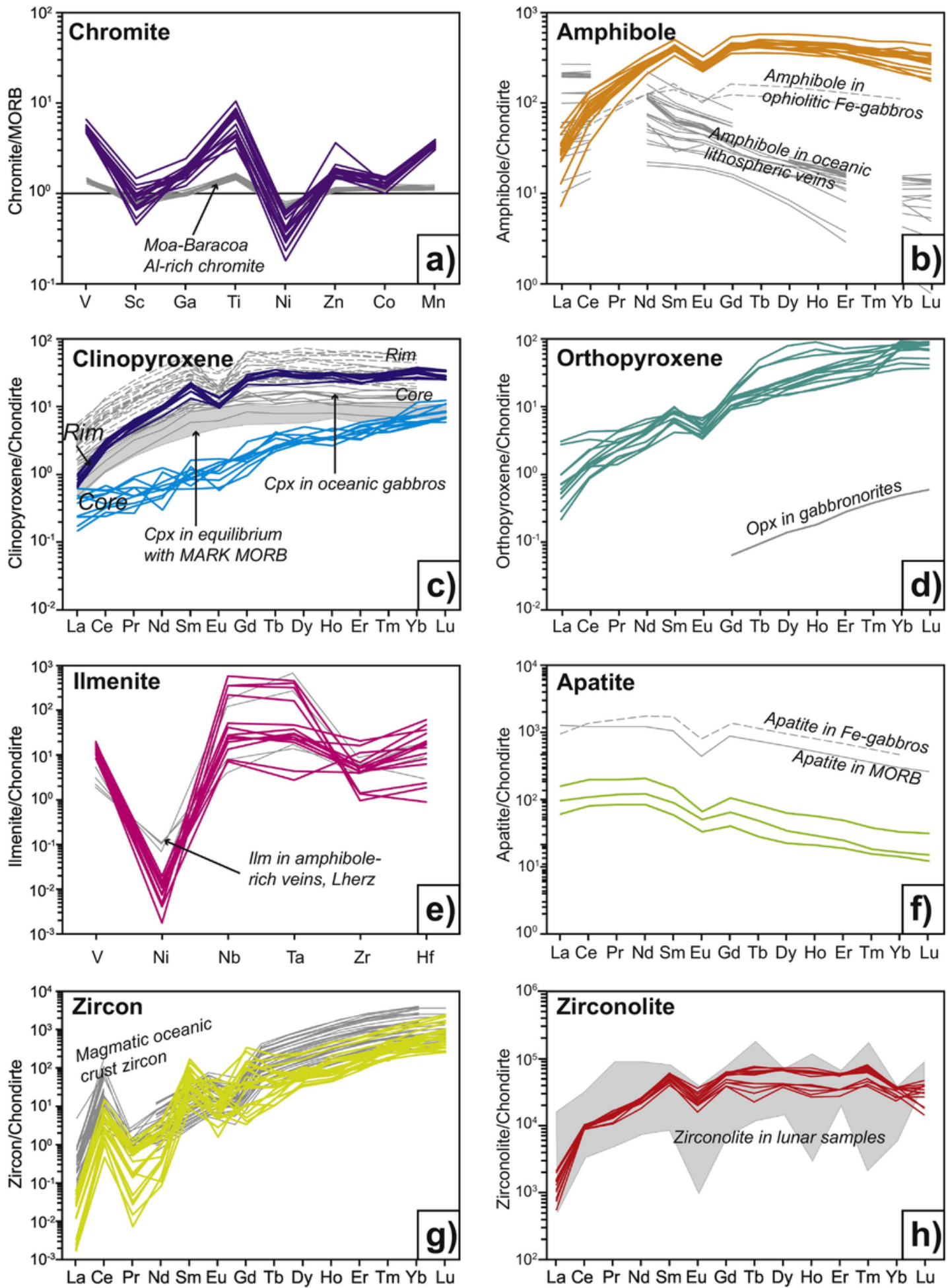

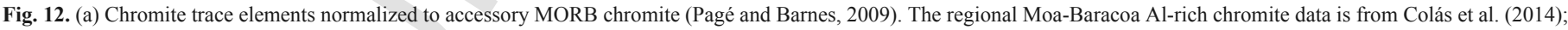

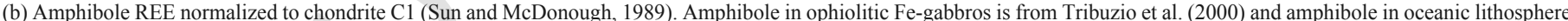

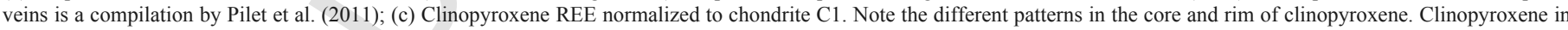

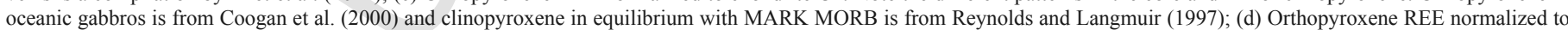

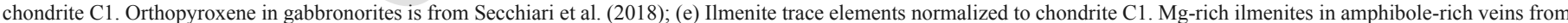

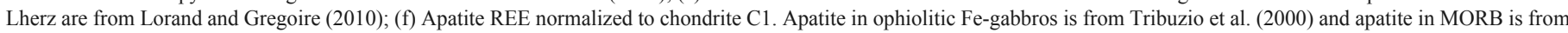

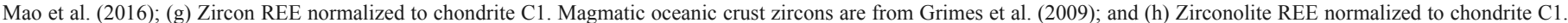
Lunar zirconolite is from Williams and Gieré (1996) and Rasmussen et al. (2008). 

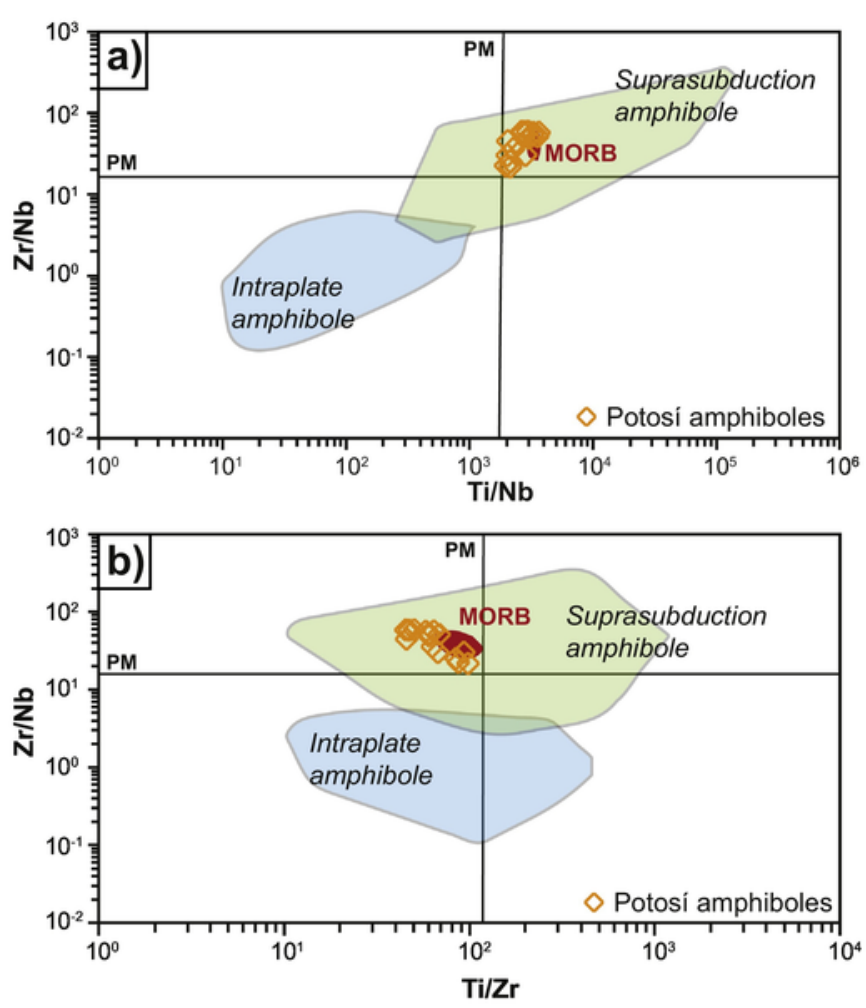

Fig. 13. Classification diagrams of amphiboles: (a) $\mathrm{Zr} / \mathrm{Nb}$ vs Ti/Nb; and (b) $\mathrm{Zr} / \mathrm{Nb}$ vs Ti/ Zr. Fields for intraplate and suprasubduction amphiboles are from Coltorti et al. (2007).

Th (450 - 6,000 ppm) (Belousova et al., 2002), and relatively flat chondrite-normalized REE patterns (Hoskin, 2005).

\subsection{Fractional crystallization and interaction of evolved melts with chromitite}

In the Moa-Baracoa ophiolite, Marchesi et al. (2007) demonstrated that the primitive lower crust layered gabbros and pegmatitic gabbros have similar $\mathrm{Sr}$ and $\mathrm{Nd}$ isotopic signatures and derived from a common isotopic DMM source, which is similar to that of the Potosí pegmatitic gabbros (in POT-1 sample; ${ }^{87} \mathrm{Sr} /{ }^{86} \mathrm{Sr}=0.702581$ and ${ }^{143} \mathrm{Nd} /{ }^{144} \mathrm{Nd}=0.513128$; unpublished data). It is then conceivable that the Potosí pegmatitic gabbro dikes formed from derivative liquids after the crystal fractionation of primitive MORB similar to those that built the Moa-Baracoa lower oceanic crust and the more primitive olivine gabbro dikes intruding Potosí chromitites. Like oceanic Fe-Ti gabbros in slow-spreading mid-ocean ridges (Chen et al., 2019; Dick et al., 2000), Potosí gabbros have an assemblage composed of clinopyroxene and plagioclase - with multiple oxide inclusions - that is distinctive of gabbroic rocks derived from MOR-like basaltic melts (with BABB-like trace element signature, Fig. 3). Under the quartz-fayalite-magnetite oxygen buffer condition, primitive MORB crystallizes olivine, clinopyroxene, plagioclase and, upon further cooling below c. $1100{ }^{\circ} \mathrm{C}, \mathrm{Fe}-\mathrm{Ti}$ oxides forming oxide gabbros (e.g. Chen et al., 2019), in agreement with the mineral assemblage observed in Potosí gabbro dikes. The low anorthite content of plagioclase $\left(\mathrm{An}_{51-56}\right.$; Appendix 5) and a rather high $\mathrm{Mg} \#(85$ - 90 mol.\%) of Potosí pegmatitic gabbros are consistent with crystallization from a rather anhydrous $(<0.5 \mathrm{wt} . \%)$ evolved MORB melt for a liquidus temperature of c. $1100{ }^{\circ} \mathrm{C}$ (Berndt et al., 2004; Feig et al., 2006). However, their high contents in REE and incompatible trace ele- ments (Fig. 12, Appendix 12), their unfractionated trace element patterns and the strong enrichments in trace elements in the rims of high-Mg\# clinopyroxene cannot solely be accounted by crystal fractionation. These geochemical features are symptomatic of post cumulus fractionation of melts in a solidifying crystal-melt mush and entrapment of residual evolved melts upon cooling (e.g. Bédard, 1994; Bodinier et al., 1986; Borghini and Rampone, 2007; Garrido et al., 2006; Langmuir, 1989). This trapped melt mechanism is well documented in continental igneous layered intrusions (Cawthorn and Tegner, 2017; Ibanez-Mejia and Tissot, 2019). In this process, the residual melts are progressively and effectively isolated from early cumulus minerals due to physical or kinetic barriers and evolve via intercumulus fractional crystallization upon cooling. Borghini and Rampone (2007) successfully modeled trace element enrichment in MORB-type primitive olivine-rich cumulates from the Erro-Tobio mantle peridotite by small-scale migration of residual evolved melt by crystal fractionation and entrapment of low fractions $(5-10 \%)$. The resulting melts are enriched in $\mathrm{REE}, \mathrm{Ti}$ and $\mathrm{Zr}$ accounting for the occurrence of accessory interstitial Ti-amphibole and Fe-Ti oxide cumulates without requiring an exotic REE- and HFSE-rich melt (Borghini and Rampone, 2007).

Proenza et al. (2001) proposed that the intrusion of gabbroic dikes into chromitites triggered the crystallization of sulfide-rich chromite ores. Here, we propose a two-stage model for the genesis of metasomatic REE- and HFSE-rich melt in Potosí chromitites. In a first stage, crystallization of evolved MORB in a crystallizing mush produced via intercumulus fractional crystallization water-rich residual melts strongly enriched in incompatible elements. In a second stage, batches of these evolved melts escaped the solidifying mush and extensively reacted and metasomatized the surrounding chromitites, crystallizing HFSE- and REE-bearing minerals and $\mathrm{Fe}-\mathrm{Cu}-\mathrm{Ni}$ sulfides. We envisage that this process occurred in a solidifying mush in dike intrusions -in a nearly closed system or with low rate of magma supply- at near solidus conditions in the conductive oceanic mantle lithosphere, allowing melts to stagnate, slowly cool and differentiate, and the residual melts to leak and react with the surrounding chromitites and peridotites (e.g. Morishita et al., 2004).

During crystallization in the crystal mush, residual melt fractions produced via an inter-cumulus fractional crystallization were progressively enriched in $\mathrm{FeO}, \mathrm{TiO}_{2}$, HFSE, $\mathrm{H}_{2} \mathrm{O}$, promoting crystallization of HFSE- and REE-bearing minerals and, upon sulfide liquid immiscibility, the $\mathrm{Fe}-\mathrm{Cu}-\mathrm{Ni}$ sulfide assemblage described by Proenza et al. (2001). To yield residual melts with enough $\mathrm{H}_{2} \mathrm{O}$ (2-6 wt.\%) to stabilize amphibole after a primitive MORB composition (0.10-0.20 wt.\% of $\mathrm{H}_{2} \mathrm{O}$ ) requires over $90 \%$ fractional crystallization driven by anhydrous mineral fractionation up to near solidus conditions (Gillis and Meyer, 2001; Tribuzio et al., 2000). This substantial degree of fractionation generated via intercumulus fractional crystallization generated near-solidus water-rich buoyant silicic melt fractions that were strongly enriched in $\mathrm{Zr}$ and other HFSE until the onset of zircon and baddeleyite saturation $\left(<900{ }^{\circ} \mathrm{C}\right.$ for melts with $\mathrm{H}_{2} \mathrm{O}>2$ wt.\%; Ibanez-Mejia and Tissot, 2019). These residual melts percolated the crystallizing mush and were progressively trapped leading to the strong whole-rock trace element enrichments of the Potosí pegmatitic gabbro dikes.

Locally, batches of these HFSE-enriched residual melts escaped the crystallizing mush and tapped into the surrounding chromitites. These water-rich siliceous residual melts were in strong disequilibrium with the surrounding chromitites, leading to extensive reaction with chromitites and metasomatism, and to the rapid consumption of the melts via melt-consuming melt-rock reactions. The substantial compositional variations in the studied minerals, especially in ilmenite, and the heterogeneous distribution of the accessory $\mathrm{Zr}$-bearing minerals indicates strong local heterogeneities in $\mathrm{SiO}_{2}, \mathrm{MgO}$, 
and HFSE, which is compatible with a kinetically-inhibited restricted system that evolved by rapid melt-rock reactions at decreasing melt mass. During this stage, Zr-bearing minerals (baddeleyite, zirconolite, srilankite) may have formed by exsolution after Zr-rich ilmenite, forming zircon coronas and likely involving residual silica-rich melt/ fluids at temperatures below the zircon saturation. These HFSE- rich residual melt that formed the particular mineral assemblage of the Potosí metasomatized chromitites derives from a BABB-like melt (MORB-like melt) in a suprasubduction environment (Marchesi et al., 2006, 2007; Proenza et al., 2001).

$\mathrm{The} \mathrm{U} / \mathrm{Pb}$ age of baddeleyite is indicative of the age of the metasomatic event (134.4 $\pm 14 \mathrm{Ma})$ that was coeval with the oceanic stage in back-arc suprasubduction settings. Similar ages were reported in igneous zircon grains from a Fe-Ti-rich gabbro intruding the mantle peridotite section of the Moa-Baracoa massif $(124 \pm 1 \mathrm{Ma}$; Rojas-Agramonte et al., 2016) and two zircons recovered from the Potosí ordinary chromitite $(99 \pm 21 \mathrm{Ma}$ and $118 \pm 8 \mathrm{Ma}$, Proenza et al., 2018). The metasomatic event is hence consistent with magmatism related to ophiolite construction, generally considered to have taken place at 90 - $125 \mathrm{Ma}$ (Iturralde-Vinent, 1996; Iturralde-Vinent et al., 2006).

\section{Concluding remarks}

The interaction between chromitites and gabbroic intrusions in Potosí (eastern Cuba ophiolite) triggered the formation of a particular HFSE-mineral assemblage including Ti-rich amphibole, Mg-rich ilmenite with inclusions of $\mathrm{Zr}$ oxides, such as baddeleyite, zirconolite and srilankite, and zircon coronas surrounding ilmenite grains. These mineral phases related to the metasomatized chromitite are also REE-rich. We propose a two-stage model for the formation of the HFSE- and REE-bearing minerals in the Potosí metasomatized chromitites: (1) crystallization of evolved MORB-like melt (BABB-like melt in a suprasubduction environment) in a crystallizing mush, producing water-rich residual melts enriched in incompatible elements via intercumulus fractional crystallization; (2) reaction of batches of the evolved residual melts that escaped the solidifying mush, with the surrounding chromitites, giving place to the observed metasomatism and the formation of HFSE- and REE-bearing minerals and $\mathrm{Fe}-\mathrm{Cu}-\mathrm{Ni}$ sulfides. This process likely occurred near solidus conditions in a nearly closed system (or with a low rate magma supply), which allowed the melts to stagnate, slowly cool, differentiate, and react with the surrounding chromitites. The age of the metasomatic event is $134.4 \pm 14 \mathrm{Ma}$, coeval with the magmatism related to ophiolite construction in eastern Cuba.

\section{Uncited references}

Garcia-Casco et al., 2008

García-Casco et al., 2008

Gonzalez-Jimenez et al., 2014

González-Jiménez et al., 2014

Grégoire et al., 2000

Ibañez-Mejia and Tissot, 2019

O'Reilly and Griffin, 2000

Pushcharovsky, 1988

\section{Declaration of Competing Interest}

The authors declare that they have no known competing financial interests or personal relationships that could have appeared to influence the work reported in this paper.

\section{Acknowledgments}

This research was financially supported by the Spanish Project CGL2015-65824 granted by the Spanish "Ministerio de Economía y Competitividad" to J.A.P., the project RTI2018-099157-A-I00 granted by the "Ministerio de Ciencia, Innovación y Universidades", the Ramón y Cajal Fellowship RYC-2015-17596 to J.M.G.-J., a FPU Ph.D. grant to N.P.-S. by the "Ministerio de Educación" of the Spanish Government, and received support for analyses at CIC from the University of Granada. Reviewers Michel Grégoire and Valentin Basch, and Lithos editor Marco Scambelluri are deeply acknowledged for their constructive criticism that has helped to greatly improve the quality of the present manuscript.

\section{Appendix A. Supplementary data}

Supplementary data to this article can be found online at https:// doi.org/10.1016/j.lithos.2020.105420.

\section{References}

Akizawa, N., Miyake, A., Ishikawa, A., Tamura, A., Terada, Y., Uesigi, K., Takeuchi, A., Arai, S., Tanaka, C., Igami, Y., Suzuki, K., Kogiso, T., 2017. Metasomatic PGE mobilization by carbonatitic melt in the mantle: evidence from sub- $\mu \mathrm{m}$-scale sulphidecarbonaceous glass inclusions in Tahitian harzburgite xenolith. Chem. Geol. 475, 87-104. https://doi.org/10.1016/j.chemgeo.2017.10.037.

Amores-Casals, S., Melgarejo, J.C., Bambi, A., Gonçalves, A.O., Morais, E.A., Manuel, J., Buta Neto, A., Costanzo, A., Martí Molist, J., 2019. Lamprophyre-carbonatite magma mingling and subsolidus processes as key controls on critical element concentration in carbonatites-The Bonga Complex (Angola). Minerals 9 (10), 601. https://doi.org/10.3390/min9100601.

Arai, S., Miura, M., 2016. Formation and modification of chromitites in the mantle. Lithos 264, 277-295. https://doi.org/10.1016/j.lithos.2016.08.039.

Austrheim, H., Putnis, C.V., Engvik, A.K., Putnis, A., 2008. Zircon coronas around Fe-Ti oxides: a physical reference frame for metamorphic and metasomatic reactions. Contrib. Mineral. Petrol. 156 (4), 517-527. https://doi.org/10.1007/s00410008-0299-8.

Azzone, R.G., Ruberti, E., Enrich, G.E., Gomes, C.B., 2009. Zr-and Ba-rich minerals from the Ponte Nova alkaline mafic-ultramafic massif, southeastern Brazil: indication of an enriched mantle source. Can. Mineral. 47 (5), 1087-1103. https://doi. org/10.3749/canmin.47.5.1087.

Barkov, A.Y., Pakhomovskii, Y.A., Men'shikov, Y.P., 1995. Baddeleyite: new occurrences from two mafic-ultramafic layered intrusions, Russia. Mineral. Mag. 59 (2), 349-353. https://doi.org/10.1180/minmag.1995.059.395.18.

Basch, V., Rampone, E., Crispini, L., Ferrando, C., Ildefonse, B., Godard, M., 2019. Multi-stage reactive formation of troctolites in slow-spreading oceanic lithosphere (Erro-Tobbio, Italy): a combined field and petrochemical study. J. Petrol. 60 (5), 873-906. https://doi.org/10.1093/petrology/egz019.

Basch, V., Rampone, E., Borghini, G., Ferrando, C., Zanetti, A., 2019. Origin of pyroxenites in the oceanic mantle and their implications on the reactive percolation of depleted melts. Contrib. Mineral. Petrol. 174 (12), 97. https://doi.org/10.1007/ s00410-019-1640-0.

Bea, F., Montero, P.G., Gonzalez-Lodeiro, F., Talavera, C., Molina, J.F., Scarrow, J.H., Whitehouse, M.J., Zinger, T., 2006. Zircon thermometry and U-Pb ion-microprobe dating of the gabbros and associated migmatites of the Variscan Toledo Anatectic Complex, Central Iberia. J. Geol. Soc. 163 (5), 847-855. https://doi.org/ 10.1144/0016-76492005-143.

Beckman, V., Möller, C., Söderlund, U., Corfu, F., Pallon, J., Chamberlain, K.R., 2014. Metamorphic zircon formation at the transition from gabbro to eclogite in Trollheimen-Surnadalen, Norwegian Caledonides. Geol. Soc. 390 (1), 403-424. https://doi.org/10.1144/SP390.26, London, Special Publications.

Beckman, V., Möller, C., Söderlund, U., Andersson, J., 2017. Zircon growth during progressive recrystallization of Gabbro to Garnet Amphibolite, Eastern segment, Sveconorwegian Orogen. J. Petrol. 58 (1), 167-187. https://doi.org/10.1093/ petrology/egx009.

Bédard, J.H., 1994. A procedure for calculating the equilibrium distribution of trace elements among the minerals of cumulate rocks, and the concentration of trace elements in the coexisting liquids. Chem. Geol. 118 (1-4), 143-153. https://doi.org/ 10.1016/0009-2541(94)90173-2.

Bedini, R.M., Bodinier, J.L., Dautria, J.M., Morten, L., 1997. Evolution of LILE-enriched small melt fractions in the lithospheric mantle: a case study from the 
East African Rift. Earth Planet. Sci. Lett. 153, 67-83. https://doi.org/10.1016/ S0012-821X(97)00167-2.

Bellatreccia, F., Ventura, G.D., Williams, C.T., Lumpkin, G.R., Smith, K.L., Colella, M., 2002. Non-metamict zirconolite polytypes from the feldspathoid-bearing alkalisyenitic ejecta of the Vico volcanic complex (Latium, Italy). Eur. J. Mineral. 14 (4), 809-820. https://doi.org/10.1127/0935-1221/2002/0014-0809.

Belousova, E., Griffin, W.L., O'Reilly, S.Y., Fisher, N.L., 2002. Igneous zircon: trace element composition as an indicator of source rock type. Contrib. Mineral. Petrol. 143 (5), 602-622. https://doi.org/10.1007/s00410-002-0364-7.

Berndt, J., Koepke, J., Holtz, F., 2004. An experimental investigation of the influence of water and oxygen fugacity on differentiation of MORB at $200 \mathrm{MPa}$. J. Petrol. 46, 135-167. https://doi.org/10.1093/petrology/egh066.

Bingen, B., Austrheim, H., Whitehouse, M., 2001. Ilmenite as a source for zirconium during high-grade metamorphism? Textural evidence from the Caledonides of western Norway and implications for zircon geochronology. J. Petrol. 42 (2), 355-375. https://doi.org/10.1093/petrology/42.2.355.

Blanco-Quintero, I.F., García-Casco, A., Rojas-Agramonte, Y., Rodríguez-Vega, A., Lázaro, C., Iturralde-Vinent, M.A., 2010. Metamorphic evolution of subducted ho oceanic crust (La Corea Melange, Cuba). Am. J. Sci. 310 (9), 889-915. https://doi. org/10.2475/11.2010.01

Blanco-Quintero, I.F., Rojas-Agramonte, Y., García-Casco, A., Kröner, A., Mertz, D.F., Lázaro, C., Blanco-Moreno, J., Renne, P.R., 2011. Timing of subduction and exhumation in a subduction channel: evidence from slab melts from La Corea mélange (eastern Cuba). Lithos 127, 86-100. https://doi.org/10.1016/j.lithos.2011. 08.009

Bodinier, J.L., Godard, M., 2003. Orogenic, ophiolitic, and abyssal peridotites. In: Carlson, R. (Ed.), Treatise on Geochemistry, 2: Mantle and Core. Elsevier, Amsterdam, pp. 103-170.

Bodinier, J.L., Guiraud, M., Dupuy, C., Dostal, J., 1986. Geochemistry of basic dikes in the Lanzo massif (Western Alps): petrogenetic and geodynamic implications. Tectonophysics 128, 77-95. https://doi.org/10.1016/0040-1951(86)90309-4

Bodinier, J.L., Vasseur, G., Vernieres, J., Dupuy, C., Fabries, J., 1990. Mechanisms of mantle metasomatism: geochemical evidence from the Lherz orogenic peridotite. J. Petrol. 31 (3), 597-628. https://doi.org/10.1093/petrology/31.3.597.

Bodinier, J.L., Merlet, C., Bedini, R.M., Simien, F., Remaidi, M., Garrido, C.J., 1996. Distribution of niobium, tantalum, and other highly incompatible trace elements in the lithospheric mantle: the spinel paradox. Geochim. Cosmochim. Acta 60, 545-550, doi: 510.1016/0016-7037(1095)00431-00439.

Bodinier, J.L., Garrido, C.J., Chanefo, I., Bruguier, O., Gervilla, F., 2008. Origin of pyroxenite-peridotite veined mantle by refertilization reactions: evidence from the Ronda peridotite (Southern Spain). J. Petrol. 49 (5), 999-1025. https://doi.org/10. 1093/petrology/egn014.

Borghini, G., Rampone, E., 2007. Postcumulus processes in oceanic-type olivine-rich cumulates: the role of trapped melt crystallization versus melt/rock interaction. Contrib. Mineral. Petrol. 154 (6), 619-633. https://doi.org/10.1007/s00410-0070217-5.

Bulakh, A.G., Nesterov, A.R., Anastasenko, G.F., Anisimov, I.S., 1999. Crystal morphology and intergrowths of calzirtite $\mathrm{Ca}_{2} \mathrm{Zr}_{5} \mathrm{Ti}_{2} \mathrm{O}_{16}$, zirkelite $(\mathrm{Ti}, \mathrm{Ca}, \mathrm{Zr}) \mathrm{O}_{2-\mathrm{x}}$, zirconolite $\mathrm{CaZrTi}_{2} \mathrm{O}_{7}$ in phoscorites and carbonatites of the Kola Peninsula (Russia) Neues Jb. Mineral. Monat. 1, 11-20.

Cárdenas-Párraga, J., García-Casco, A., Proenza, J.A., Harlow, G.E., Blanco-Quintero, I.F., Lázaro, C., Villanova-de-Benavent, C., Núñez Cambra, K., 2017. Trace-element geochemistry of transform-fault serpentinite in high-pressure subduction mélanges (eastern Cuba): Implications for subduction initiation. Int. Geol. Rev. 59 (16), 2041-2064. https://doi.org/10.1080/00206814.2017.1308843.

Carlier, G., Lorand, J.P., 2003. Petrogenesis of a zirconolite-bearing Mediterranean-type lamproite from the Peruvian Altiplano (Andean Cordillera). Lithos 69 (1), 15-35. https://doi.org/10.1016/S0024-4937(03)00045-8.

Carlier, G., Lorand, J.P., 2008. Zr-rich accessory minerals (titanite, perrierite, zirconolite, baddeleyite) record strong oxidation associated with magma mixing in the south Peruvian potassic province. Lithos 104 (1-4), 54-70. https://doi.org/10.1016/ j.lithos.2007.11.008

Cawthorn, R.G., Tegner, C., 2017. Modeling incompatible trace-element abundances in plagioclase in the Skaergaard intrusion using the trapped liquid shift effect. Contrib. Mineral. Petrol. 172, 93. https://doi.org/10.1007/s00410-017-1411-8.

Charlier, B., Skår, , Korneliussen, A., Duchesne, J.C., Vander Auwera, J., 2007. Ilmenite composition in the Tellnes Fe-Ti deposit, SW Norway: fractional crystallization, postcumulus evolution and ilmenite-zircon relation. Contrib. Mineral. Petrol. 154 (2), 119-134. https://doi.org/10.1007/s00410-007-0186-8.

Chen, Y., Niu, Y., Wang, X., Gong, H., Guo, P., Gao, Y., Shen, F., 2019. Petrogenesis of ODP Hole 735B (Leg 176) oceanic plagiogranite: partial melting of gabbros or advanced extent of fractional crystallization?. Geochem. Geophys. Geosyst. 20, 2717-2732. https://doi.org/10.1029/2019gc008320.

Clague, D.A., Frey, F.A., Thompson, G., Rindge, S., 1981. Minor and trace element geochemistry of volcanic rocks dredged from the Galapagos Spreading Center Role of crystal fractionation and mantle heterogeneity. J. Geophys. Res. 86, 9469-9482. https://doi.org/10.1029/JB086iB10p09469.
Cobiella-Reguera, J.L., 2005. Emplacement of Cuban ophiolites. Geol. Acta 3, 273-294.

Colás, V., González-Jiménez, J.M., Griffin, W.L., Fanlo, I., Gervilla, F., O'Reilly, S.Y., Pearson, N.J., Kerestedjian, T., Proenza, J.A., 2014. Fingerprints of metamorphism in chromite: new insights from minor and trace elements. Chem. Geol. 389, 137-152. https://doi.org/10.1016/j.chemgeo.2014.10.001.

Coltorti, M., Bonadiman, C., Hinton, R.W., Siena, F., Upton, B.G.J., 1999. Carbonatite metasomatism of the oceanic upper mantle: evidence from clinopyroxenes and glasses in ultramafic xenoliths of Grande Comore, Indian Ocean. J. Petrol. 40, 303-320. https://doi.org/10.1093/petroj/40.1.133.

Coltorti, M., Beccaluva, L., Bonadiman, C., Salvini, L., Siena, F., 2000. Glasses in mantle xenoliths as geochemical indicators of metasomatic agents. Earth Planet. Sci. Lett. 183, 303-320. https://doi.org/10.1016/S0012-821X(00)00274-0.

Coltorti, M., Beccaluva, L., Bonadiman, C., Faccini, B., Ntaflos, T., Siena, F., 2004. Amphibole genesis via metasomatic reaction with clinopyroxene in mantle xenoliths from Victoria Land, Antarctica. Lithos 75, 115-139. https://doi.org/10.1016/j. lithos.2003.12.021

Coltorti, M., Bonadiman, C., Faccini, B., Grégoire, M., O'Reilly, S.Y., Powell, W., 2007. Amphiboles from suprasubduction and intraplate lithospheric mantle. Lithos 99 (1-2), 68-84. https://doi.org/10.1016/j.lithos.2007.05.009.

Constantin, M., 1999. Gabbroic intrusions and magmatic metasomatism in harzburgites from the Garret transform fault: implications for the nature of the mantle-crust transition at fast-spreading ridges. Contrib. Mineral. Petrol. 136 (1-2), 111-130. https://doi.org/10.1007/s004100050527.

Coogan, L.A., Saunders, A.D., Kempton, P.D., Norry, M.J., 2000. Evidence from oceanic gabbros for porous melt migration within a crystal mush beneath the Mid-Atlantic Ridge. Geochem. Geophys. Geosyst. 1 (9)https://doi.org/10.1029/ 2000GC000072.

Coogan, L.A., Wilson, R.N., Gillis, K.M., MacLeod, C.J., 2001. Near-solidus evolution of oceanic gabbros: insights from amphibole geochemistry. Geochim. Cosmochim. Acta 65 (23), 4339-4357. https://doi.org/10.1016/S0016-7037(01)007141.

Cortesogno, L., Gaggero, L., Zanetti, A., 2000. Rare earth and trace elements in igneous and high-temperature metamorphic minerals of oceanic gabbros (MARK area, Mid-Atlantic Ridge). Contrib. Mineral. Petrol. 139 (4), 373-393. https://doi. org/10.1007/s004100000147.

Currin, A., Wolff, P.E., Koepke, J., Almeev, R.R., Zhang, C., Zihlmann, B., Ildefonse, B., Teagle, D.A.H., 2018. Chlorine-rich amphibole in deep layered gabbros as evidence for brine/rock interaction in the lower oceanic crust: A case study from the Wadi Wariyah, Samail Ophiolite, Sultanate of Oman. Lithos 323, 125-136. https:// doi.org/10.1016/j.lithos.2018.09.015.

Dawson, J.B., 2002. Metasomatism and partial melting in upper-mantle peridotite xenoliths from Lashaine volcano, northern Tanzania. J. Petrol. 43, 1749-1777. https://doi.org/10.1093/petrology/43.9.1749.

Dawson, J.B., Smith, J.V., 1977. The MARID (mica-amphibole-rutile-ilmenite-diopside) suite of xenoliths in kimberlite. Geochim. Cosmochim. Acta 41 (2), 309-323 https://doi.org/10.1016/0016-7037(77)90239-3.

De Hoog, J.C.M., Van Bergen, M.J., 2000. Volatile-induced transport of HFSE, REE, $\mathrm{Th}$ and $\mathrm{U}$ in arc magmas: evidence from zirconolite-bearing vesicles in potassic lavas of Lewotolo volcano (Indonesia). Contrib. Mineral. Petrol. 139, 465-502. https://doi.org/10.1007/s004100000146.

Della Ventura, G., Bellatreccia, F., Williams, C.T., 2000. Zirconolite with significant $\mathrm{REEZrNb}(\mathrm{Mn}, \mathrm{Fe}) \mathrm{O}_{7}$ from a xenolith of the Laacher See eruptive center, Eifel volcanic region, Germany. Can. Mineral. 38 (1), 57-65.

Dick, H.J.B., Natland, J.H., Alt, J.C., Bach, W., Bideau, D., Gee, J.S., Haggas, S., Hertogen, J.G.H., Hirth, G., Holm, P.M., Ildefonse, B., Iturrino, G.J., John, B.E., Kelley, D.S., Kikawa, E., Kingdon, A., LeRux, P.J., Maeda, J., Meyer, P.S., Miller, D.J., Naslund, H.R., Niu, Y.-L., Robinson, P.T., Snow, J., Stephen, R.A., Trimby, P.W., Worm, H.-U., Yoshinobu, A., 2000. A long in situ section of the lower ocean crust: results of ODP Leg 176 drilling at the Southwest Indian Ridge. Earth Planet. Sci. Lett. 179, 31-51. https://doi.org/10.1016/S0012-821X(00)00102-3.

Drouin, M., Godard, M., Ildefonse, B., Bruguier, O., Garrido, C.J., 2009. Geochemical and petrographic evidence for magmatic impregnation in the oceanic lithosphere at Atlantis Massif, Mid-Atlantic Ridge (IODP Hole U1309D, 30 N). Chem. Geol. 264 (1-4), 71-88. https://doi.org/10.1016/j.chemgeo.2009.02.013.

Ernst, W.G., Liu, J., 1998. Experimental phase-equilibrium study of Al-and Ti-contents of calcic amphibole in MORB-A semiquantitative thermobarometer. Am. Mineral. 83 (9-10), 952-969. https://doi.org/10.2138/am-1998-9-1004.

Feig, S.T., Koepke, J., Snow, J.E., 2006. Effect of water on tholeiitic basalt phase equilibria: an experimental study under oxidizing conditions. Contrib. Mineral. Petrol. 152, 611-638. https://doi.org/10.1007/s00410-006-0123-2.

Ferry, J.M., Watson, E.B., 2007. New thermodynamic models and revised calibrations for the Ti-in-zircon and Zr-in-rutile thermometers. Contrib. Mineral. Petrol. 154 (4), 429-437. https://doi.org/10.1007/s00410-007-0201-0.

Fitzpayne, A., Giuliani, A., Hergt, J., Phillips, D., Janney, P., 2018. New geochemical constraints on the origins of MARID and PIC rocks: Implications for mantle metasomatism and mantle-derived potassic magmatism. Lithos 318, 478-493. https:// doi.org/10.1016/j.lithos.2018.08.036. 
Flint, D.E., de Albear, J.F., Guild, P.W., 1948. Geology and chromite deposits of the Camagüey district, Camagüey Province, Cuba. US Geol. Surv. Bull. 954-B, 39-63.

Fujimaki, H., Tatsumoto, M., Aoki, K.I., 1984. Partition coefficients of Hf, Zr, and REE between phenocrysts and groundmasses. J. Geophys. Res. Solid Earth 89 (S02), B662-B672. https://doi.org/10.1029/JB089iS02p0B662.

Garcia-Casco, A., Torres-Roldán, R.L., Iturralde-Vinent, M.A., Millán, G., Núñez Cambra, K., Lázaro, C., Rodríguez Vega, A., 2006. High pressure metamorphism of ophiolites in Cuba. Geol. Acta 4, 63-88. https://doi.org/10.1344/105. 000000358

Garcia-Casco, A., Iturralde-Vinent, M.A., Pindell, J., 2008. Latest Cretaceous collision/accretion between the Caribbean Plate and Caribeana: origin of metamorphic terranes in the Greater Antilles. Int. Geol. Rev. 50, 781-809. https://doi.org/10. 2747/0020-6814.50.9.781.

Garcia-Casco, A., Lázaro, C., Rojas-Agramonte, Y., Kröner, A., Torres Roldán, R.L., Núñez, K., Millán, G., Neubaurer, F., Quitero, I., 2008. Partial melting and counterclockwise P-T path of subducted oceanic crust (Sierra del Convento, E Cuba). J. Petrol. 49, 129-161. https://doi.org/10.1093/petrology/egm074.

Garrido, C.J., Bodinier, J.-L., Burg, J.-P., Zeilinger, G., Hussain, S.S., Dawood, H., Chaudhry, M.N., Gervilla, F., 2006. Petrogenesis of Mafic Garnet Granulite In The Lower Crust of The Kohistan Paleo-Arc Complex (Northern Pakistan): Implications For Intra-Crustal Differentiation of Island Arcs And Generation of Continental Crust. J. Petrol. 47, 1873-1914. https://doi.org/10.1093/petrology/egl030.

Gervilla, F., Proenza, J.A., Frei, R., González-Jiménez, J.M., Garrido, C.J., Melgarejo, J.C., Meibom, A., Díaz-Martinez, R., Lavaut, W., 2005. Distribution of platinum-group elements and Os isotopes in chromite ores from Mayarí-Baracoa Ophiolitic Belt (eastern Cuba). Contrib. Mineral. Petrol. 150, 589-607. https://doi. org/10.1007/s00410-005-0039-2.

Gillis, K.M., Meyer, P.S., 2001. Metasomatism of oceanic gabbros by late stage melts and hydrothermal fluids: Evidence from the rare earth element composition of amphiboles. Geochem. Geophys. Geosyst. 2 (3)https://doi.org/10.1029/ $2000 \mathrm{GC} 000087$.

Gillis, K.M., Thompson, G., 1993. Metabasalts from the Mid-Atlantic Ridge: new insights into hydrothermal systems in slow-spreading crust. Contrib. Mineral. Petrol. 113 (4), 502-523. https://doi.org/10.1007/BF00698319.

Gillis, K.M., Thompson, G., Kelley, D.S., 1993. A view of the lower crustal component of hydrothermal systems at the Mid-Atlantic Ridge. J. Geophys. Res. Solid Earth 98 (B11), 19597-19619. https://doi.org/10.1029/93JB01717.

González-Jiménez, J.M., Proenza, J.A., Gervilla, F., Melgarejo, J.C., Blanco-Moreno, J.A., Ruiz-Sánchez, R., Griffin, W.L., 2011. High-Cr and high-Al chromitites from the Sagua de Tánamo district, Mayarí-Cristal Ophiolitic Massif (eastern Cuba): constraints on their origin from mineralogy and geochemistry of chromian spinel and platinum group elements. Lithos 125, 101-121. https://doi.org/10.1016/j. lithos.2011.01.016.

González-Jiménez, J.M., Griffin, W.L., Proenza, J.A., Gervilla, F., O'Reilly, S.Y., Akbulut, M., Pearson, N.J., Arai, S., 2014. Chromitites in ophiolites: how, where, when, why? Part II. The crystallization of chromitites. Lithos 189, 140-158. https: //doi.org/10.1016/j.lithos.2013.09.008.

González-Jiménez, J.M., Villaseca, C., Griffin, W.L., O'Reilly, S.Y., Belousova, E., Ancochea, E., Pearson, N.J., 2014. Significance of ancient sulphides PGE and Re-Os signatures in the mantle beneath Calatrava, Central Spain. Contrib. Mineral. Petrol. 168, 1047. https://doi.org/10.1007/s00410-014-1047-x.

Govindaraju, K., 1994. Compilation of working values and sample description for 383 geostandards. Geostand. Geoanal. Res. 18, 1-158. https://doi.org/10.1111/j.1751908X.1994.tb00502.x

Grégoire, M., Lorand, J.-P., O'Reilly, S.Y., Cottin, J.Y., 2000. Armalcolite-bearing, Ti-rich metasomatic assemblages in harzburgitic xenoliths from the Kerguelen Islands: implications for the oceanic mantle budget of high-field strength elements. Geochim. Cosmochim. Acta 64, 673-694. https://doi.org/10.1016/S00167037(99)00345-2.

Grégoire, M., Bell, D., Le Roex, A., 2002. Trace element geochemistry of phlogopite-rich mafic mantle xenoliths: their classification and their relationship to phlogopite-bearing peridotites and kimberlites revisited. Contrib. Mineral. Petrol. 142 (5), 603-625. https://doi.org/10.1007/s00410-001-0315-8.

Grimes, C.B., John, B.E., Cheadle, M.J., Mazdab, F.K., Wooden, J.L., Swapp, S., Schwartz, J.J., 2009. On the occurrence, trace element geochemistry, and crystallization history of zircon from in situ ocean lithosphere. Contrib. Mineral. Petrol. 158 (6), 757. https://doi.org/10.1007/s00410-009-0409-2.

Guild, P.W., 1947. Petrology and structure of the Moa Chromite District, Oriente province, Cuba. Am. Geophys. Union 28, 218-264.

Hawthorne, F.C., Oberti, R., Harlow, G.E., Maresch, W.V., Martin, R.F., Schumacher, J.C., Welch, M.D., 2012. Nomenclature of the amphibole supergroup. Am. Mineral. 97 (11-12), 2031-2048. https://doi.org/10.2138/am.2012.4276.

Heaman, L.M., LeCheminant, A.N., 1993. Paragenesis and U-Pb systematics of baddeleyite $\left(\mathrm{ZrO}_{2}\right)$. Chem. Geol. 110 (1-3), 95-126. https://doi.org/10.1016/0009 2541(93)90249-I.

Hornig, I., Wörner, G., 1991. Zirconolite-bearing ultrapotassic veins in a mantle xenolith from Mt. Melbourne Volcanic Field, Victoria Land, Antarctica. Contrib. Mineral. Petrol. 106, 355-366. https://doi.org/10.1007/BF00324563.
Hoskin, P.W., 2005. Trace-element composition of hydrothermal zircon and the alteration of Hadean zircon from the Jack Hills, Australia. Geochim. Cosmochim. Acta 69 (3), 637-648. https://doi.org/10.1016/j.gca.2004.07.006.

Hoskin, P.W., Schaltegger, U., 2003. The composition of zircon and igneous and metamorphic petrogenesis. Rev. Mineral. Geochem. 53 (1), 27-62. https://doi.org/10. 2113/0530027.

Hurai, V., Huraiová, M., Gajdošová, M., Konečný, P., Slobodník, M., Siegfried, P.R., 2017. Compositional variations of zirconolite from the Evate apatite deposit (Mozambique) as an indicator of magmatic-hydrothermal conditions during post-orogenic collapse of Gondwana. Mineral. Petrol.1-18. https://doi.org/10. 1007/s00710-017-0538-7.

Hurai, V., Paquette, J.L., Huraiová, M., Slobodník, M., Hvožd’ara, P., Siegfried, P., Gajdošová, M., Milovská, S., 2017. New insights into the origin of the Evate apatite-iron oxide-carbonate deposit, Northeastern Mozambique, constrained by mineralogy, textures, thermochronometry, and fluid inclusions. Ore Geol. Rev. 80, 1072-1091. https://doi.org/10.1016/j.oregeorev.2016.09.017.

Ibanez-Mejia, M., Tissot, F.L., 2019. Extreme $\mathrm{Zr}$ stable isotope fractionation during magmatic fractional crystallization. Sci. Adv. 5 (12)https://doi.org/10.1126/sciadv. aax8648, eaax 8648 .

Ionov, D.A., Gregoire, M., Ashchepkov, I., 1999. Feldspar-Ti oxide metasomatism in off-cratonic continental and oceanic upper mantle. Earth Planet. Sci. Lett. 165, 37-44. https://doi.org/10.1016/S0012-821X(98)00253-2.

Iturralde-Vinent, M., 1996. Geología de las ofiolitas de Cuba. In: Iturralde-Vinent, M. (Ed.), Ofiolitas y arcos volcánicos de Cuba: IGCP Project 432, Miami, USA. pp. $83-120$.

Iturralde-Vinent, M.A., Díaz-Otero, C., Rodríguez-Vega, A., Díaz-Martínez, R., 2006. Tectonic implications of paleontologic dating of Cretaceous-Danian sections of Eastern Cuba. Geol. Acta 4, 89-102. https://doi.org/10.1344/105.000000359.

Iturralde-Vinent, M.A., Garcia-Casco, A., Rojas-Agramonte, Y., Proenza, J.A., Murphy, J.B., Stern, R.G., 2016. The geology of Cuba: a brief overview and synthesis. GSA Today 26 (10), 4-10. https://doi.org/10.1130/GSATG296A.1.

Jang, Y.D., Naslund, H.R., 2003. Major and trace element variation in ilmenite in the Skaergaard Intrusion: petrologic implications. Chem. Geol. 193 (1-2), 109-125. https://doi.org/10.1016/S0009-2541(02)00224-3.

Juster, T.C., Grove, T.L., Perfit, M.R., 1989. Experimental constraints on the generation of Fe-Ti basalts, andesites and rhyodacites at the Galapagos Spreading Center, $85^{\circ} \mathrm{W}$ and $95^{\circ} \mathrm{W}$. J. Geophys. Res. 94, 9215-9247. https://doi.org/10.1029/ JB094iB07p09251.

Kapsiotis, A., Ewing Rassios, A., Antonelou, A., Tzamos, E., 2016. Genesis and multi-episodic alteration of zircon-bearing chromitites from the ayios stefanos mine, othris Massif, Greece: assessment of an unconventional hypothesis on the origin of zircon in ophiolitic chromitites. Minerals 6 (4), 124. https://doi.org/10. 3390/min6040124.

Kelemen, P.B., Dick, H.J., Quick, J.E., 1992. Formation of harzburgite by pervasive melt/rock reaction in the upper mantle. Nature 358 (6388), 635. https://doi.org/10. 1038/358635a0

Kelemen, P.B., Hitehead, J.A., Aharonov, E., Jordahl, K.A., 1995. Experiments on flow focussing in soluble porous media, with applications to melt extraction from the mantle. J. Geophys. Res. 100, 475-496. https://doi.org/10.1029/94JB02544.

Kelemen, P.B., Shimizu, N., Salters, V.J., 1995. Extraction of mid-ocean-ridge basalt from the upwelling mantle by focused flow of melt in dunite channels. Nature 375 (6534), 747. https://doi.org/10.1038/375747a0

Koepke, J., Feig, S., Snow, J., 2005. Late stage magmatic evolution of oceanic gabbros as a result of hydrous partial melting: evidence from the Ocean Drilling Program (ODP) Leg 153 drilling at the Mid-Atlantic Ridge. Geochem. Geophys. Geosyst. 6 (2)https://doi.org/10.1029/2004GC000805.

Kovalchuk, N.S., Shumilova, T.G., 2014. Rare Earth and Zirconium-Niobium mineralization in diamondiferous carbonatites of Fuerteventura (Spain). IG Komi SC UB RAS 10, 28-34.

Kovaleva, E., Klötzli, U., 2017. NanoSIMS study of seismically deformed zircon: Evidence of $\mathrm{Y}, \mathrm{Yb}, \mathrm{Ce}$, and $\mathrm{P}$ redistribution and resetting of radiogenic $\mathrm{Pb}$. Am. Mineral. 102 (6), 1311-1327. https://doi.org/10.2138/am-2017-5975.

Langmuir, C.H., 1989. Geochemical consequences of in situ crystallization. Nature 340, 199-205. https://doi.org/10.1038/340199a0

Laurora, A., Mazzucchelli, M., Rivalenti, G., Vannucci, R., Zanetti, A., Barbieri, M.A., Cingolani, C., 2001. Metasomatism and melting in carbonated peridotite xenoliths from the mantle wedge: the Gobernador Gregores case (Southern Patagonia). J. Petrol. 42, 69-87. https://doi.org/10.1093/petrology/42.1.69.

Lázaro, C., García-Casco, A., Neubaurer, F., Rojas-Agramonte, Y., Kröner, A., Iturralde-Vinent, M.A., 2009. Fifty-five-million-year history of oceanic subduction and exhumation in the northern edge of the Caribbean plate (Sierra del Convento mélange, Cuba). J. Metamorph. Geol. 27, 19-40. https://doi.org/10.1111/j.15251314.2008.00800.x.

Lázaro, C., Blanco-Quintero, I.F., Rojas-Agramonte, Y., Proenza, J.A., Núñez-Cambra, K., García-Casco, A., 2013. First description of a metamorphic sole related to ophiolite obduction in the northern Caribbean: Geochemistry and petrology of the Güira de Jauco amphibolite complex (eastern Cuba) and tectonic implications. Lithos 179, 193-210. https://doi.org/10.1016/j.lithos.2013.08.019. 
Lázaro, C., Garcia-Casco, A., Blanco-Quintero, I.F., Rojas- Agramonte, Y., Corsini, M., Proenza, J.A., 2015. Did the Turonian-Coniacian plume pulse trigger subduction initiation in the Northern Caribbean? Constraints from ${ }^{40} \mathrm{Ar} /{ }^{39} \mathrm{Ar}$ dating of the Moa-Baracoa metamorphic sole (eastern Cuba). Int. Geol. Rev. 57 (5-8), 919-942. https://doi.org/10.1080/00206814.2014.924037.

Lázaro, C., Blanco-Quintero, I.F., Proenza, J.A., Rojas-Agramonte, Y., Neubauer, F., Núñez-Cambra, K., García-Casco, A., 2016. Petrogenesis and ${ }^{40} \mathrm{Ar} /{ }^{39} \mathrm{Ar}$ dating of proto-forearc crust in the Early Cretaceous Caribbean arc: the La Tinta mélange (eastern Cuba) and its easterly correlation in Hispaniola. Int. Geol. Rev. 58 (4), 1020-1040. https://doi.org/10.1080/00206814.2015.1118647.

Le Roux, V., Bodinier, J.L., Tommasi, A., Alard, O., Dautria, J.M., Vauchez, A., Riches, A.J.V., 2007. The Lherz spinel lherzolite: refertilized rather than pristine mantle. Earth Planet. Sci. Lett. 259 (3-4), 599-612. https://doi.org/10.1016/j.epsl. 2007.05.026.

Leblanc, M., Dautria, J.M., Girod, M., 1982. Magnesian ilmenitite xenoliths in a basanite from Tahalra, Ahaggar (Southern Algeria). Contrib. Mineral. Petrol. 79 (4), 347-354. https://doi.org/10.1007/BF01132063.

Lenoir, X., Garrido, C.J., Bodinier, J.L., Dautria, J.M., Gervilla, F., 2001. The recrystallization front of the Ronda peridotite: evidence for melting and thermal erosion of subcontinental lithospheric mantle beneath the Alboran Basin. J. Petrol. 42 (1), 141-158. https://doi.org/10.1093/petrology/42.1.141.

Lewis, J.F., Draper, G., Proenza, J.A., Espaillat, J., Jiménez, J., 2006. Ophiolite-related ultramafic rocks (serpentinites) in the Caribbean region: a review of their occurrence, composition, origin, emplacement and nickel laterite soils. Geol. Acta 4, 237-263. https://doi.org/10.1344/105.000000368.

Locock, A.J., 2014. An Excel spreadsheet to classify chemical analyses of amphiboles following the IMA 2012 recommendations. Comput. Geosci. 62, 1-11. https://doi org/10.1016/j.cageo.2013.09.011.

Lorand, J.P., Gregoire, M., 2010. Petrogenesis of Fe-Ti oxides in amphibole-rich veins from the Lherz orogenic peridotite (Northeastern Pyrénées, France). Contrib. Mineral. Petrol. 160 (1), 99-113. https://doi.org/10.1007/s00410-009-0468-4.

Lorand, J.-P., Delpech, G., Grégoire, M., Moine, B., O'Reilly, S.Y., Cottin, J.Y., 2004 Platinum-group elements and the multistage metasomatic history of Kerguelen lithospheric mantle (South Indian Ocean). Chem. Geol. 208, 195-215. https://doi. org/10.1016/j.chemgeo.2004.04.012

Mao, M., Rukhlov, A.S., Rowins, S.M., Spence, J., Coogan, L.A., 2016. Apatite trace element compositions: a robust new tool for mineral exploration. Econ. Geol. 111 (5), 1187-1222. https://doi.org/10.2113/econgeo.111.5.1187.

Marchesi, C., Garrido, C.J., Godard, M., Proenza, J.A., Gervilla, F., Blanco-Moreno, J., 2006. Petrogenesis of highly depleted peridotites and gabbroic rocks from the Mayarí-Baracoa Ophiolitic Belt (eastern Cuba). Contrib. Mineral. Petrol. 151 (6), 717. https://doi.org/10.1007/s00410-006-0089-0.

Marchesi, C., Garrido, C.J., Bosch, D., Proenza, J.A., Gervilla, F., Monié, P., Rodriguez-Vega, A., 2007. Geochemistry of Cretaceous magmatism in eastern Cuba: recycling of North American continental sediments and implications for subduction polarity in the Greater Antilles Paleo-arc. J. Petrol. 48, 1813-1840. https://doi. org/10.1093/petrology/egm040.

McCallum, I.S., Charette, M.P., 1978. Zr and Nb partition coefficients: implications for the genesis of mare basalts, KREEP and sea floor basalts. Geochim. Cosmochim. Acta 42 (6), 859-869. https://doi.org/10.1016/0016-7037(78)90098-4.

McKay, G., Wagstaff, J., Yang, S.R., 1986. Zirconium, hafnium, and rare earth element partition coefficients for ilmenite and other minerals in high-Ti lunar mare basalts: An experimental study. J. Geophys. Res. Solid Earth 91 (B4), 229-237. https://doi.org/10.1029/JB091iB04p0D229.

Menzies, M.A., Hawkesworth, C.J., 1987. Mantle metasomatism. Academic Press London.

Meyer, P.S., Dick, H.J., Thompson, G., 1989. Cumulate gabbros from the Southwest Indian Ridge, 54 S-7 16' E: implications for magmatic processes at a slow spreading ridge. Contrib. Mineral. Petrol. 103 (1), 44-63. https://doi.org/10.1007/ BF00371364.

Mitchell, R.H., 1977. Geochemistry of magnesian ilmenites from kimberlites in South Africa and Lesotho. Lithos 10 (1), 29-37. https://doi.org/10.1016/00244937(77)90028-7

Morishita, T., Maeda, J., Miyashita, S., Matsumoto, T., Dick, H.J., 2004. Magmatic srilankite $\left(\mathrm{Ti}_{2} \mathrm{ZrO}_{6}\right)$ in gabbroic vein cutting oceanic peridotites: an unusual product of peridotite-melt interactions beneath slow-spreading ridges. Am. Mineral. 89 (5-6), 759-766. https://doi.org/10.2138/am-2004-5-609.

Morisset, C.E., Scoates, J.S., 2008. Origin of zircon rims around ilmenite in mafic plutonic rocks of Proterozoic anorthosite suites. Can. Mineral. 46 (2), 289-304. https: //doi.org/10.3749/canmin.46.2.289.

Nakamura, Y., Fujimaki, H., Nakamura, N., Tatsumoto, M., McKay, G.A., Wagstaff, J., 1986. Hf, Zr, and REE partition coefficients between ilmenite and liquid: implications for lunar petrogenesis. J. Geophys. Res. Solid Earth 91 (B4), 239-250. https://doi.org/10.1029/JB091iB04p0D239.

Naslund, H.R., 1987. Lamellae of baddeleyite and Fe-Cr-spinel in ilmenite from the Basistoppen sill, East Greenland. Can. Mineral. 25 (1), 91-96.
O'Reilly, S.Y., Griffin, W.L., 2000. Apatite in the mantle: implications for metasomatic processes and high heat production in Phanerozoic mantle. Lithos 53 (3-4), 217-232. https://doi.org/10.1016/S0024-4937(00)00026-8.

O'Reilly, S.Y., Griffin, W.L., 2013. Mantle metasomatism. In: Harlov, D.E., Austrheim, H. (Eds.), Metasomatism and the Chemical Transformation of Rock: The Role of Fluids in Terrestrial and Extraterrestrial Processes. Lecture Notes in Earth System Sciences. Springer-Verlag, Berlin, Heidelberg, pp. 471-533. https://doi. org/10.1007/978-3-642-28394-9 12.

Pagé, P., Barnes, S.J., 2009. Using trace elements in chromites to constrain the origin of podiform chromitites in the Thetford Mines ophiolite, Québec, Canada. Econ. Geol. 104 (7), 997-1018. https://doi.org/10.2113/econgeo.104.7.997.

Pascal, M.L., Di Muro, A., Fonteilles, M., Principe, C., 2009. Zirconolite and calzirtite in banded forsterite-spinel-calcite skarn ejecta from the 1631 eruption of Vesuvius: inferences for magma-wallrock interactions. Mineral. Mag. 73 (2), 333-356. https: //doi.org/10.1180/minmag.2009.073.2.333.

Pertsev, A.N., Aranovich, L.Y., Prokofiev, V.Y., Bortnikov, N.S., Cipriani, A., Simakin, S.S., Borisovskiy, S.E., 2015. Signatures of residual melts, magmatic and seawater-derived fluids in oceanic lower-crust gabbro from the Vema lithospheric section, Central Atlantic. J. Petrol. 56 (6), 1069-1088. https://doi.org/10.1093/ petrology/egv028.

Pietranik, A., Storey, C., Koepke, J., Lasalle, S., 2017. Zircon record of fractionation, hydrous partial melting and thermal gradients at different depths in oceanic crust (ODP Site 735B, South-West Indian Ocean). Contrib. Mineral. Petrol. 172 (2-3), 10. https://doi.org/10.1007/s00410-016-1324-y.

Pilet, S., Baker, M.B., Stolper, E.M., 2008. Metasomatized lithosphere and the origin of alkaline lavas. Science 320 (5878), 916-919. https://doi.org/10.1126/science. 1156563.

Pilet, S., Baker, M.B., Müntener, O., Stolper, E.M., 2011. Monte Carlo simulations of metasomatic enrichment in the lithosphere and implications for the source of alkaline basalts. J. Petrol. 52 (7-8), 1415-1442. https://doi.org/10.1093/petrology/ egr007.

Prichard, H.T., Cann, J.R., 1982. Petrology and mineralogy of dredged gabbro from Gettysburg Bank, Eastern Atlantic. Contrib. Mineral. Petrol. 79 (1), 46-55. https:// doi.org/10.1007/BF00376960.

Proenza, J.A., Gervilla, F., Melgarejo, J.C., 1999. La Moho Transition Zone en el macizo ofiolítico Moa-Baracoa (Cuba): Un ejemplo de interacción magma/peridotita. Rev. Soc. Geol. Esp. 12 (3-4), 309-327.

Proenza, J., Gervilla, F., Melgarejo, J.C., Bodinier, J.L., 1999. Al- and Cr- rich chromitites from the Mayarí-Baracoa Ophiolitic Belt (eastern Cuba): consequence of interaction between volatile-rich melts and peridotite in suprasubduction mantle. Econ. Geol. 94, 547-566. https://doi.org/10.2113/gsecongeo.94.4.547.

Proenza, J., Gervilla, F., Melgarejo, J., Vera, O., Alfonso, P., Fallick, A., 2001. Genesis of sulfide-rich chromite ores by the interaction between chromitite and pegmatitic olivine-norite dikes in the Potosi Mine (Moa-Baracoa ophiolitic massif, eastern Cuba). Mineral. Deposita 36 (7), 658-669. https://doi.org/10.1007/ s001260100193.

Proenza, J.A., Díaz-Martínez, R., Iriondo, A., Marchesi, C., Melgarejo, J.C., Gervilla F., Garrido, C.J., Rodríguez-Vega, A., Lozano-Santacruz, R., Blanco-Moreno, J.A., 2006. Primitive Cretaceous island-arc volcanic rocks in eastern Cuba: the Téneme Formation. Geol. Acta 4 (1-2), 103-121. https://doi.org/10.1344/105. 000000360 .

Proenza, J.A., González-Jiménez, J.M., Garcia-Casco, A., Belousova, E., Griffin, W.L., Talavera, C., Rojas-Agramonte, Y., Aiglsperger, T., Navarro-Ciurana, D., Pujol-Solà, N., Gervilla, F., O'Reilly, S.Y., Jacob, D.E., 2018. Cold plumes trigger contamination of oceanic mantle wedges with continental crust-derived sediments: Evidence from chromitite zircon grains of eastern Cuban ophiolites. Geosci. Front. 9 (6), 1921-1936. https://doi.org/10.1016/j.gsf.2017.12.005.

Pushcharovsky, Y. (Ed.), 1988. Mapa geológico de la República de Cuba escala 1:250000: Academias de Ciencias de Cuba y la URSS

Python, M., Ceuleneer, G., 2003. Nature and distribution of dykes and related melt migration structures in the mantle section of the Oman ophiolite. Geochem. Geophys. Geosyst. 4 (7)https://doi.org/10.1029/2002GC000354.

Rampone, E., Borghini, G., Basch, V., 2018. Melt migration and melt-rock reaction in the Alpine-Apennine peridotites: Insights on mantle dynamics in extending lithosphere. Geosci. Front. https://doi.org/10.1016/j.gsf.2018.11.001, In Press.

Rasmussen, B., Fletcher, I.R., Muhling, J.R., 2008. Pb/Pb geochronology, petrography and chemistry of $\mathrm{Zr}$-rich accessory minerals (zirconolite, tranquillityite and baddeleyite) in mare basalt 10047. Geochim. Cosmochim. Acta 72 (23), 5799-5818. https://doi.org/10.1016/j.gca.2008.09.010.

Reynolds, J.R., Langmuir, C.H., 1997. Petrological systematics of the Mid-Atlantic Ridge south of Kane: Implications for ocean crust formation. J. Geophys. Res. Solid Earth 102 (B7), 14915-14946. https://doi.org/10.1029/97JB00391.

Rojas-Agramonte, Y., Garcia-Casco, A., Kemp, A., Kröner, A., Proenza, J.A., Lázaro, C., Liu, D., 2016. Recycling and transport of continental material through the mantle wedge above subduction zones: A Caribbean example. Earth Planet. Sci. Lett. 436, 93-107. https://doi.org/10.1016/j.epsl.2015.11.040.

Santos, J.J.A., Pimenta, A.C.S., Rosa, M.L.S., Conceição, H., 2015. Primeira ocorrência de zirconolita na Província Alcalina do Sul do da Bahia: intrusã 
o sienítica do Complexo Alcalino Floresta Azul, Bahia, NE Brasil. Scientia Plena $11(9)$.

Scamberulli, M., Vannucci, R., De Stefano, A., Preite-Martinez, M., Rivalenti, G., 2009. $\mathrm{CO}_{2}$ fluid and silicate glass as monitors of alkali basalt/peridotite interaction in the mantle wedge beneath Gobernador Gregores, Southern Patagonia. Lithos 107, 121-133. https://doi.org/10.1016/j.lithos.2008.06.015.

Scoates, J.S., Chamberlain, K.R., 1995. Baddeleyite $\left(\mathrm{ZrO}_{2}\right)$ and zircon $\left(\mathrm{ZrSiO}_{4}\right)$ from anorthositic rocks of the Laramie anorthosite complex, Wyoming: Petrologic consequences and U-Pb ages. Am. Mineraolgist 80 (11-12), 1317-1327. https://doi. org/10.2138/am-1995-11-1223.

Secchiari, A., Montanini, A., Bosch, D., Macera, P., Cluzel, D., 2018. The contrasting geochemical message from the New Caledonia gabbronorites: insights on depletion and contamination processes of the sub-arc mantle in a nascent arc setting. Contrib. Mineral. Petrol. 173 (8), 66. https://doi.org/10.1007/s00410-018-1496-8.

Sláma, J., Košler, J., Pedersen, R.B., 2007. Behaviour of zircon in high-grade metamorphic rocks: evidence from $\mathrm{Hf}$ isotopes, trace elements and textural studies. Contrib. Mineral. Petrol. 154 (3), 335-356. https://doi.org/10.1007/s00410-0070196-6.

Söderlund, P., Söderlund, U., Möller, C., Gorbatschev, R., Rodhe, A., 2004. Petrology and ion microprobe $\mathrm{U}-\mathrm{Pb}$ chronology applied to a metabasic intrusion in southern Sweden: a study on zircon formation during metamorphism and deformation. Tectonics 23 (5)https://doi.org/10.1029/2003TC001498.

Soustelle, V., Tommasi, A., Bodinier, J.L., Garrido, C.J., Vauchez, A., 2009. Deformation and reactive melt transport in the mantle lithosphere above a large-scale partial melting domain: the Ronda Peridotite massif, Southern Spain. J. Petrol. 50, 1235-1266. https://doi.org/10.1093/petrology/egp032.

Stucki, A., Trommsdorff, V., Günther, D., 2001. Zirconolite in metarodingites of Penninic Mesozoic ophiolites Central Alps. Schweiz. Mineral. Petrogr. Mitt. 81 (2), 257-265.

Sun, S.S., McDonough, W.F., 1989. Chemical and isotopic systematics of oceanic basalts: implications for mantle composition and processes. Geol. Soc. Lond., Spec. Publ. 42 (1), 313-345. https://doi.org/10.1144/GSL.SP.1989.042.01.19.

Tassara, S., González-Jiménez, J.M., Reich, M., Saunders, E., Luguet, A., Morata, D., Grégoire, M., van Acken, D., Schilling, M.E., Barra, F., Nowell, G., Corgne, A., 2018. Highly siderophile elements mobility in the subcontinental lithospheric mantle beneath southern Patagonia. Lithos 314, 579-596. https://doi.org/10.1016/j. lithos.2018.06.022.

Taylor, L.A., McCallister, R.H., 1972. An experimental investigation of the significance of zirconium partitioning in lunar ilmenite and ulvöspinel. Earth Planet. Sci. Lett. 17 (1), 105-109. https://doi.org/10.1016/0012-821X(72)90264-6.

Tiepolo, M., Bottazzi, P., Foley, S.F., Oberti, R., Vannucci, R., Zanetti, A., 2001. Fractionation of $\mathrm{Nb}$ and $\mathrm{Ta}$ from $\mathrm{Zr}$ and $\mathrm{Hf}$ at mantle depths: the role of titanian pargasite and kaersutite. J. Petrol. 42 (1), 221-232. https://doi.org/10.1093/petrology/42. 1.221 .

Tompkins, L.A., Haggerty, S.E., 1985. Groundmass oxide minerals in the Koidu kimberlite dikes, Sierra Leone, West Africa. Contrib. Mineral. Petrol. 91 (3), 245-263. https://doi.org/10.1007/BF00413351.
Tribuzio, R., Riccardi, M.P., Ottolini, L., 1995. Trace element redistribution in high-temperature deformed gabbros from East Ligurian ophiolites (Northern Apennines, Italy): constraints on the origin of syndeformation fluids. J. Metamorph. Geol. 13 (3), 367-377. https://doi.org/10.1111/j.1525-1314.1995.tb00226. $\mathrm{x}$.

Tribuzio, R., Tiepolo, M., Thirlwall, M.F., 2000. Origin of titanian pargasite in gabbroic rocks from the Northern Apennine ophiolites (Italy): insights into the late-magmatic evolution of a MOR-type intrusive sequence. Earth Planet. Sci. Lett. 176 (3-4), 281-293. https://doi.org/10.1016/S0012-821X(00)00014-5.

Tribuzio, R., Renna, M.R., Dallai, L., Zanetti, A., 2014. The magmatic-hydrothermal transition in the lower oceanic crust: clues from the Ligurian ophiolites, Italy. Geochim. Cosmochim. Acta 130, 188-211. https://doi.org/10.1016/j.gca.2014.01. 010 .

Vanko, D.A., 1986. High-chlorine amphiboles from oceanic rocks; product of highly-saline hydrothermal fluids?. Am. Mineral. 71 (1-2), 51-59.

Vanko, D.A., Stakes, D.S., 1991. Fluids in oceanic layer 3: evidence from veined rocks, Hole 735B, Southwest Indian Ridge. In: Proceedings of the Ocean Drilling Program - Scientific Results. vol. 118, pp. 181-215. https://doi.org/10.2973/odp. proc.sr.118.121.1991.

Warren, J.M., Shimizu, N., 2010. Cryptic variations in abyssal peridotite compositions: evidence for shallow-level melt infiltration in the oceanic lithosphere. J. Petrol. 51 (1-2), 395-423. https://doi.org/10.1093/petrology/egp096.

Watson, E.B., Wark, D.A., Thomas, J.B., 2006. Crystallization thermometers for zircon and rutile. Contrib. Mineral. Petrol. 151 (4), 413. https://doi.org/10.1007/ s00410-006-0068-5.

Williams, C.T., Gieré, R., 1996. Zirconolite: a review of localities worldwide, and a compilation of its chemical compositions. Bull. British Nat. History Mus. (Geological Service) 52, 1-24.

Xu, J., Melgarejo, J.C., Castillo-Oliver, M., 2018. Ilmenite as a recorder of kimberlite history from mantle to surface: examples from Indian kimberlites. Mineral. Petrol. 112 (2), 569-581. https://doi.org/10.1007/s00710-018-0616-5.

Yao, S., 1999. Chemical Composition of Chromites from Ultramafic Rocks: Application to Mineral Exploration and Petrogenesis (PhD thesis). Macquarie University, Sydney, (174 pp).

Zaccarini, F., Stumpfl, E.F., Garuti, G., 2004. Zirconolite and Zr-Th-U minerals in chromitites of the Finero complex, Western Alps, Italy: evidence for carbonatite-type metasomatism in a subcontinental mantle plume. Can. Mineral. 42 (6), 1825-1845. https://doi.org/10.2113/gscanmin.42.6.1825.

Zack, T., Brumm, R., 1998. Ilmenite/liquid partition coefficients of 26 trace elements determined through ilmenite/clinopyroxene partitioning in garnet pyroxenites. Int. Kimberlite Conf. 7 (1), 986-988.

Zhang, C., Koepke, J., Albrecht, M., Horn, I., Holtz, F., 2017. Apatite in the dike-gabbro transition zone of mid-ocean ridge: Evidence for brine assimilation by axial melt lens. Am. Mineral. 102 (3), 558-570. https://doi.org/10.2138/am-2017-5906. 